University of Nebraska - Lincoln

DigitalCommons@University of Nebraska - Lincoln

\title{
The Effects of Belowground Resources on Aboveground Allometric Growth in Bornean Tree Species
}

\author{
Katherine D. Heineman \\ University of Nebraska-Lincoln, kheineman@life.illinois.edu \\ Ethan Jensen \\ University of Nebraska-Lincoln \\ Autumn Shapland \\ University of Nebraska-Lincoln \\ Brett Bogenrief \\ University of Nebraska-Lincoln \\ Sylvester Tan \\ Sarawak Forestry Corporation, Kuching, Sarawak, Malaysia \\ See next page for additional authors
}

Follow this and additional works at: https://digitalcommons.unl.edu/bioscifacpub

Part of the Life Sciences Commons

Heineman, Katherine D.; Jensen, Ethan; Shapland, Autumn; Bogenrief, Brett; Tan, Sylvester; Rebarber, Richard; and Russo, Sabrina E., "The Effects of Belowground Resources on Aboveground Allometric Growth in Bornean Tree Species" (2011). Faculty Publications in the Biological Sciences. 172.

https://digitalcommons.unl.edu/bioscifacpub/172

This Article is brought to you for free and open access by the Papers in the Biological Sciences at DigitalCommons@University of Nebraska - Lincoln. It has been accepted for inclusion in Faculty Publications in the Biological Sciences by an authorized administrator of DigitalCommons@University of Nebraska - Lincoln. 


\section{Authors}

Katherine D. Heineman, Ethan Jensen, Autumn Shapland, Brett Bogenrief, Sylvester Tan, Richard Rebarber, and Sabrina E. Russo 


\title{
The Effects of Belowground Resources on Aboveground Allometric Growth in Bornean Tree Species
}

\author{
Katherine D. Heineman, ${ }^{1}$ Ethan Jensen, ${ }^{1}$ Autumn Shapland, ${ }^{1}$ Brett Bogenrief, ${ }^{1}$ \\ Sylvester Tan, ${ }^{3}$ Richard Rebarber, ${ }^{2}$ Sabrina E. Russo ${ }^{1}$
}

\author{
1. School of Biological Sciences, University of Nebraska-Lincoln, Lincoln, Nebraska, USA \\ 2. Department of Mathematics, University of Nebraska-Lincoln, Lincoln, Nebraska, USA \\ 3. Center for Tropical Forest Science and Forest Research Centre, Sarawak Forestry Corporation, Kuching, Sarawak, Malaysia \\ Corresponding author - K. D. Heineman, email kheineman@life.illinois.edu
}

\begin{abstract}
Tree height and crown allometries reflect adaptations for resource acquisition and structural stability, as well as plastic responses to a heterogeneous environment. While both light and soil resources limit growth and influence competitive responses in tropical forests, the effects of belowground resources on allometries are less understood, especially within the understory. To characterize outcomes of tree competition along an edaphic resource gradient, we quantified variation in height and crown allometries of six Bornean tree species from contrasting regeneration niches (lightdemanding vs. shade-tolerant) on two soil habitats (clay-fine loam and sandy loam) within a 52-ha forest dynamics plot. Using empiricallyfit allometric parameters and diameter growth rates from plot census data, we modeled tree height and crown area growth over the projected life span of each species. Based on resource competition theory, we hypothesized that tree species specializing on and populations of generalist species growing on the relatively moister, more fertile clay-fine loam soil habitat would have faster height and crown growth rates, compared to those on the sandy loam habitat, regardless of regeneration niche. Among soil specialists and within generalists of both genera, trees growing on clay-fine loam had taller stems and larger crowns at a given age and faster height and crown area growth rates at most sizes than trees on sandy loam. Differences in height and crown growth were driven by the faster diameter growth rates of trees on clay-fine loam, not by differences in height- and crown-diameter allometries, as trees on sandy loam were significantly taller at a given diameter, and differences in crown allometry were not consistent across soil habitats. Characterizing the height and crown growth responses of trees along resource gradients provides insight into the mechanisms that maintain diversity in tropical forests. Our results point to the importance of adaptive and plastic responses to both above- and belowground resource availability in determining the allometric growth of trees and suggest that this diversity of responses may contribute tree species coexistence through competition-based trade-off mechanisms and variation in growth among individuals. Additionally, as the importance estimating natural carbon sequestration increases with the escalating effects of anthropogenic climate change, differences in tree growth and architecture across soil habitats also have implications for the approximation of forest carbon storage on heterogeneous tropical soils.
\end{abstract}

Keywords: crown architecture, crown area expansion, height growth, resource competition, resource gradients, tree growth models, tree growth strategies

\section{Introduction}

In any forest, the allometry of tree growth, that is, relative changes in tree size and shape, is both a cause and a consequence of variation in resource availability. Trees with wide, spreading crowns simultaneously preempt light interception and shade out nearby competitors (Canham et al., 1994; Weiner, 1990). Ade quate availability of soil resources enables allocation to rapid height growth, allowing faster-growing species to over-top their neighbors and grow into a bet- ter light environment (Coomes et al., 2009; King, 1981, 1990a; Kohyama, 1987; Tilman, 1988). Allometries can therefore be viewed as evolutionary outcomes reflecting dynamic strategies of competition for above- and belowground resources (Halle et al., 1978; Horn, 1971), as well as plastic responses to a spatially and temporally variable environment (Clark, 2010; Dietze et al., 2008).

Variation in allometric growth can promote coexistence among species and, consequently, can be viewed as maintaining diversity in plant communities (Grubb, 1977; Kohyarna 
et al., 1999). Along resource gradients in forests, tree species are observed to have different growth strategies (e.g., Kobe, 1999), in part because adaptations that promote survival in resource-poor environments may reduce competitive ability when resources are more abundant, and, conversely, because of the survival-costs of fast growth (Chapin et al., 1993; Grime, 1979; Rose et al., 2009). Therefore, competitive growth strategies, which allow trees to rapidly overtop and shadeout their neighbors, may be selected for in environments that are relatively less limited in resources, whereas conservative strategies that sacrifice rapid growth maybe favored in more resource-limited environments (Chapin et al., 1993; Grime, 1979; Rose et al., 2009). Tradeoffs in demographic rates among tree species provide evidence for these proposed strategies, since tree species aggregating where resources are abundant experience heightened growth, but lower survival rates, relative to trees that cluster where light (Kobe et al., 1995; Poorter and Arets, 2003) and soil resources (Russo et al., 2008) are scarce. Thus, as adaptations for resource acquisition, tree allometries can be viewed as influencing species distributions along resource gradients (Givnish, 1995; Kobe, 1999).

One hypothesis to explain tree species' distributions along gradients defined by soil resources (e.g., mineral nutrients and water) is that as belowground resources become relatively more available, aboveground competition for light intensifies (resource competition theory; Newman, 1973; Tilman, 1988). Under this hypothesis, tree species characteristic of soils with greater resource supply rates should have a more competitive strategy of faster aboveground growth rates, as compared with species characteristic of soils with reduced resource supply rates (Newman, 1973; Tilman, 1988). Although it is wellknown that tree species found primarily on soils with greater resource availability have faster diameter growth rates than those on resource-poor sites (e.g., Russo et al., 2005), competition for light is better defined in terms of growth in tree height and crown area (King, 1990b). Yet, how growth in these aboveground dimensions varies with belowground resource availability is less well known, particularly in tropical forests, even though the allometric adaptations linked with growth strategies in high versus low light environments are well documented (e.g., King, 1994; Kohyama, 1987, 1991; Poorter et al., 2003). Forestry models to quantify site index in temperate forests indicate that dominant canopy trees are generally taller at a given age on more resource-rich sites, although habitat factors contributing to forest productivity are not always clearly identifiable (e.g., Broadfoot, 1969; Carmean, 1979; Monserud, 1984; Weiskittel et al., 2007). However, height-age relationships are difficult to determine in a seasonal tropical forests (Vanclay, 1992), and site indices typically exclude subcanopy species, which constitute a substantial proportion of the diversity of tropical forests (Ashton and Hall, 1992).

Here we examine soil-related patterns of variation in allometric growth in subcanopy tropical tree species and consider how these patterns reflect hypothesized differences in competitive strategies of tree species along resource gradients. We used empirically parameterized models of height and crown area growth to compare tree species' competitive strategies along an edaphic gradient in a Bornean rainforest. Height and crown allometries and mean wood density were quantified in six subcanopy tree species from the mixed-dipterocarp tropical rain forest of Lambir Hills National Park (hereafter, Lambir) in Malaysian Borneo. There is striking floristic contrast along the edaphic gradient at Lambir because most tree species are found on only one or two soil habitats (Figure SM1, Davies et al., 2005). Here, we focus on the two extremes of this gradient: the resource-rich soil class, consisting of the two moist, relatively nutrient-rich soils types, clay and fine loam (with sampling preference for clay), which were contrasted with the better-drained, nutrient-poor sandy loam (Baillie et al., 2006).Additionally, consistent with resource competition theory, light availability varies inversely to soil resources, with the forest understory on sandy loam receiving on average $20 \%$ more total mean daily photosynthetic photon flux density than on the clay (Russo et al., 2010; S.E. Russo, unpub. data), suggesting that the intensity of competition for light is greater on clay than on sandy loam. We therefore expected trees species' allometric growth strategies to differ between these soil habitats due to variation in above- and belowground resources.

Our study species represent two genera contrasting in shade tolerance: Macaranga (Euphorbiaceae), a light-demanding genus, and Knema (Myristicaceae), a shade-tolerant genus. From each genus, we selected one clay and one sandy loam specialist species, forming a phylogenetically-controlled interspecific contrast of allometries to test whether tree species of divergent soil specialization also had divergent allometric growth strategies. We also evaluated whether any soil-related differences that we found were consistent across shade-tolerance groupings, since light-demanding species are generally more responsive to environmental variability (Bazzaz, 1979), and soil nutrients are often more limiting to their growth, compared to late successional, shade-tolerant species (Burslem et al., 1994, 1995; Coomes and Grubb, 1998). Interspecific variation in allometry results from both adaptive variation and plastic responses to the environment. Therefore, we sampled one generalist species from each genus on both soil habitats to assess population-level variation in allometric growth. We predicted that tree allometry would vary with soil resources in accordance with resource competition theory (Newman, 1973; Tilman, 1988). Tree species specializing on the moister, more fertile clay-fine loam soil at Lambir were expected to have faster rates of height and crown area growth, compared to specialists of the drier, less fertile sandy loam. In other words, clay specialists should be taller and have more spreading crowns at a given age because their growth strategy is for light-preemption. They should also have shallower crowns to avoid self-shading within the crown (Horn, 1971). We further expected clay specialists to have reduced height safety factors (i.e. to be taller at a given diameter; sensu Niklas, 1992) and to exhibit wider crowns at a given size because where competition for light is greatest, structural stability should be relatively less important than height growth and crown expansion. We predicted that populations of generalist species growing on each soil type would exhibit similar patterns of soil-related variation in allometric growth strategies as soil specialists.

\section{Materials and methods}

\subsection{Study site and species}

Data were collected from the lowland, mixed-dipterocarp forest of Lambir Hills National Park in Sarawak, Malaysia $\left(4^{\circ} 11^{\prime} \mathrm{N}, 114^{\circ} 01^{\prime} \mathrm{E}\right)$. Lambir receives ca. 3,000 $\mathrm{mm}$ of rainfall each year with $>100 \mathrm{~mm}$ of precipitation each month (Watson, 1985). The 52-ha forest dynamics plot at Lambir, established in 1991, is situated in the most diverse forest known in the Old World tropics (Ashton and Hall, 1992; Lee et al., 2002). Using standard methods (Condit, 1998a,b), all woody stems in the plot $\geq 1 \mathrm{~cm}$ in diameter at breast height $(\mathrm{DBH}, 1.3 \mathrm{~m})$ are tagged, mapped, identified to species, and measured for $\mathrm{DBH}$ with re-censuses every five years.

The gradient of soils at Lambir ranges from relatively nutrientpoor, well-drained, and humus-rich, sandstone-based coarse loams to relatively more fertile, moist, and humus-poor, shalederived clay soils (Baillie et al., 2006; Lee et al., 2002). From this gradient, Davies et al. (2005) defined four soil types listed in order of increasing fertility: sandy loam, loam, fine loam, and clay. On the Lambir plot, each $20 \mathrm{~m} \times 20 \mathrm{~m}$ subplot was categorized into one of the four soil types based on total C, N, and Pand ex- 
Table 1. Study species, including soil specialization, regeneration niche, and number of individuals sampled for height and crown allometries ( $N$ ) and wood density $(W)$, and abundance on the Lambir plot. Modulus of elasticity was approximated as a function of wood density (see methods). For generalists, demographic information is listed for each species overall and for individuals on sandy loam and clay. For each species, the individual with the largest DBH recorded in the 2003 Lambir census was included in our sample.

\begin{tabular}{|c|c|c|c|c|c|c|c|}
\hline Scientific name & Family & Soil specialization & Regeneration niche & DBH range $(\mathrm{cm})$ & Height range $(\mathrm{m})$ & $N(W)$ & Abundance \\
\hline Knema galeata & Myristicaceae & Sandy loam & ST & $1.0-20.6$ & $2.2-28.8$ & $31(5)$ & 709 \\
\hline Knema elmeri & Myristicaceae & Clay & ST & $1.0-24.6$ & $1.6-24.9$ & $29(8)$ & 31 \\
\hline Macaranga lamellata & Euphorbiaceae & Sandy loam & LD & $0.9-11.0$ & $1.9-23.5$ & $37(11)$ & 344 \\
\hline Knema latericia & Myristicaceae & Generalist & ST & $1.3-17.1$ & $1.8-24.4$ & $71(5)$ & 1078 \\
\hline Sandy loam & & & & 1.3-17.1 & $1.8-24.4$ & $36(1)$ & 1007 \\
\hline Clay-fine loam & & & & $1.3-10.5$ & $1.8-16.1$ & $35(4)$ & 71 \\
\hline Macaranga beccariana & Euphorbiaceae & Generalist & $\mathrm{LD}$ & $1.9-16.4$ & $4.0-25.9$ & $79(18)$ & 656 \\
\hline \multicolumn{2}{|l|}{ Scientific name } & \multicolumn{2}{|c|}{ Wood density $\left(\mathrm{kg} / \mathrm{m}^{3}\right)$} & \multicolumn{4}{|c|}{ Modulus of elasticity $\left(\mathrm{N} / \mathrm{m}^{2}\right)$} \\
\hline & \multicolumn{2}{|l|}{0.655} & \multicolumn{4}{|l|}{-1744} \\
\hline \multicolumn{2}{|l|}{ Knema elmeri } & \multicolumn{2}{|l|}{0.549} & \multicolumn{4}{|l|}{-1748} \\
\hline \multicolumn{2}{|l|}{ Macaranga lamellata } & \multirow{2}{*}{\multicolumn{2}{|c|}{$\begin{array}{l}0.628 \\
0.507\end{array}$}} & \multirow{2}{*}{\multicolumn{4}{|c|}{$\begin{array}{l}-1745 \\
-1749\end{array}$}} \\
\hline \multicolumn{2}{|l|}{ Macaranga umbrosa } & & & & & & \\
\hline Knema latericia & & \multicolumn{2}{|l|}{0.596} & \multicolumn{4}{|l|}{-1746} \\
\hline Clay-fine loam & & & & & & & \\
\hline
\end{tabular}

Abbreviations: $\mathrm{ST}=$ shade-tolerant, $\mathrm{LD}=$ light-demanding.

changeable $\mathrm{K}, \mathrm{Ca}, \mathrm{Mg}$ and elevation at a $20 \mathrm{~m} \times 20 \mathrm{~m}$ scale (Davies et. al., 2005). Mineral nutrient concentrations and properties of each soil type are reported in Baillie et al. (2006) and Tan et al. (2009), and soil volumetric water contents for sandy loam and clay soils are reported in Russo et al. (2010).

Davies et al. (2005) identified tree species in Lambir showing spatial distribution patterns biased with respect to these four soil types using a stochastic point-process model that replicates small-scale (e.g. dispersal-driven) spatial aggregation while reducing large-scale (e.g. habitat-driven) aggregation, therebytaking into account spatial autocorrelation (Plotkin et al., 2000). These analyses indicated that the majority of species at Lambir display statistically significant associations with one or two soil types (soil specialists), and fewer species occur with similar abundances on all soil types (generalists). Soil specialization categories defined by Davies et al. (2005) within the Lambir plot are largely consistent with analyses of floristic differences among soil habitats at larger spatial scales within the region (Potts et al., 2002). Our six study species (Table 1) represent four soil specialists and two generalists, as categorized by analyses in Davies et al. (2005), from two genera differing in lightdefined regeneration niche: Macaranga (Euphorbiaceae), a genus of faster-growing and light-demanding trees (Davies et al., 1998), and Knema (Myristicaceae), a genus of slower-growing, shade-tolerant trees (deWilde, 2000). These genera were selected to evaluate whether soil-related differences in aboveground growth are consistent across regeneration niches. From each genus, we chose one clay specialist and one sandy loam because, to the extent that these genera are reciprocally monophyletic, paired congeners provide phylogenetically-controlled interspecific comparison of allometric growth between soil types. For generalists, we sampled individuals on both sandy loam and clay-fine loam to quantify population-level variation in allometric growth among soil habitats. All study species are monopodial, subcanopy trees at maturity.

\subsection{Tree allometry sampling and measurements}

Trees sampled for allometry spanned the range of diameters for the study species in the Lambir plot and nearby forest (1.0-24.6 cm, Table 1). All individuals sampled from sandy loam, the most abundant soil habitat at Lambir, were selected randomly from the plot with the exception of the five largest trees from each species, which were systematically included to ensure sampling of the full range of diameters. However, since clay soil is less prevalent at Lambir, there are fewer individuals to sample within the plot. Therefore, clay specialists, M. lamellata and K. elmeri, and individuals from generalist M. beccariana growing on clay were exhaustively sampled from the plot, and we supplemented the sample size for these species from (1) trees located within the plot adjacent to clay on soil classified as fine loam, the soil type most similar to clay in soil texture, waterholding capacity, and fertility (Baillie et al., 2006) and (2) with trees on nearby clay soil located off the plot. Of trees randomly selected from the plot, ca. 3\% were excluded from our study because they had either severely bent stems or crowns too difficult to distinguish from the surrounding foliage.

For each tree, we measured $\mathrm{DBH}$, vertical stem height, height to the lowest leaf, and eight crown radii. Height was measured with measuring tape for trees $\leq 2 \mathrm{~m}$ tall. For taller trees leaning $<5^{\circ}$ from vertical, stem height was estimated using trigonometry from the perpendicular distance from the observer's eye to the stem (measured using a laser range finder or measuring tape) and the tangents of the angles to the top leaf and base of the tree (measured using a clinometer). For trees leaning $>5^{\circ}$ from vertical ( $\sim 8 \%$ of our sample), the distances and the sines of the angles from the observer to the top leaf and tree base were used to calculate height. Height to the lowest leaf was estimated the same way and used to calculate crown depth (stem height-height to lowest leaf). Crown radii were measured in eight directions (N, NE, E, SE, S, SW, W, and $\mathrm{NW}$ ) as the distance from the stem to the outermost leaf. Crown area (CA) was then calculated as the summed area of

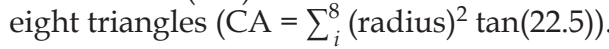

\subsection{Wood properties}

Wood density $(p)$ for each species was quantified from trees $(>3 \mathrm{~cm}$ in DBH) sampled off-plot. For trees $>6 \mathrm{~cm}$ in $\mathrm{DBH}$, trees were cored at breast height with an increment borer (5$\mathrm{mm}$ in diameter) to a depth equal to one half of the $\mathrm{DBH}$. Wood samples from trees $<6 \mathrm{~cm}$ in $\mathrm{DBH}$ were taken from branch seg- 
ments $10 \mathrm{~cm}$ in length and $>1 \mathrm{~cm}$ in diameter. After extraction, cores andbranch segments were placed in drinking straws and resealable bags, respectively, and stored cold until they were processed (within $48 \mathrm{~h}$ of collection). Bark was removed from all core and branch samples, and cores were cut into segments $\leq 5 \mathrm{~cm}$ in length to allow weighting of specific gravity estimates to account for differences in density between older and younger wood. Each segment was submerged in water in a pre-tared graduated cylinder, and fresh volume was determined from the mass of water displaced. Each segment was dried to constant mass at $60^{\circ} \mathrm{C}$. Wood density $(p)$ in $\mathrm{kg} / \mathrm{m}^{3}$ was calculated for each tree as: $\left.p=\sum_{i=2}^{n}\left(M_{i} / V_{i}\right)\left(L_{i}^{2}-L_{i-1}^{2}\right) / L_{\text {max }}^{2}\right)$ for $n$ segments, where $L_{i}$ is the length, $M_{i}$ is the mass, and $V_{i}$ is the volume of segment $i$, and $L_{\max }$ is the length of the entire wood sample.

We predicted Young's modulus of elasticity $(E)$ and green wood density $(S)$ for each species based on our estimates of specific gravity. To predict $E$ from $p$, we fit the relationship between species average $E$ and $p$ values reported in the literature for 30 tropical tree species (van Gelder et al., 2006) and 127 commercially important timber species (United States Department of Agriculture, 1999) using ordinary least squares regression. Of the models tested, the following third-order polynomial explained the greatest proportion of variation in $E$ due to $p\left(R^{2}=0.76\right): E(p)=-1767+4.01 \mathrm{E}-5 \times p^{3}-0.05 \times p^{2}+34.63$ $\times p$, where $E$ is in units of $N / \mathrm{m}^{2}$. We estimated green wood density $(S)$ in $\mathrm{kg} / \mathrm{m}^{3}$ as: $S=w \times p(1+c / 100)$, where $w$ is the density of water $\left(1,000 \mathrm{~kg} / \mathrm{m}^{3}\right)$ and $c$ is percent wood moisture content (Simpson, 1993). We used species-specific values of $c$ reported in Suzuki (1999). Critical height $\left(H_{c r}\right)$, the theoretical height at which a tree of a given DBH would buckle under its own weight, was calculated as $H_{c r}=0.792[E /(g S)]^{1 / 3} \mathrm{DBH}^{2 / 3}$ (Greenhill, 1881), where $g$ is the gravitational force per unit mass on Earth $(9.8 \mathrm{~N} / \mathrm{kg})$. A height safety factor, defined as the ratio of $H_{c r}$ to realized height $H$ (sensu Niklas, 1992), was used as a metric of tree mechanical stability.

\subsection{Allometric models and analysis}

We used these data to (1) quantify parameters for height$\mathrm{DBH}$, crown area-DBH, and crown depth-height allometry for our six study species, (2) to test the interspecific and intraspecific effects of soil resource variation and regeneration niche on tree allometry and height safety factors, and (3) to predict height and crown growth over time using allometric parameters and diameter growth rates. All mathematical modeling and statistical analysis was performed in the statistical software package, R (The R Core Development Team, 2009).

\subsubsection{Allometric scaling relationships}

Allometric scaling relationships were modeled as power functions of the form $Y=a X^{b}$, where $X$ is the independent variable, $Y$ is the response variable, and $a$ and $b$ are fitted parameters. Stem height $(H)$ and crown area $(\mathrm{CA})$ were modeled as functions of $D$, and crown depth (CD) was modeled as a function of $H$ since this trait most closely correlates with the crown's position in the vertical light gradient.

Since trees often reach an asymptotic height $\left(H_{\max }\right)$, we also tested the fit of the $H-D$ allometry using the function: $H=$ $H_{\max }\left[1-\exp \left(-a D^{b}\right)\right]$ (Thomas, 1996). This model failed to converge for all but one species, K. elmeri, as no other species reached an asymptotic height, and so power functions were used.

Allometric power functions can be linearized by taking the $\log$ of both sides: $\operatorname{In}(Y)=b \times \operatorname{In}(X)+\operatorname{In}(a)$. Allometric parameters could be fit either to linearized models using ordinary least squares (OLS) regression or to unlogged power functions using nonlinear least squares (NLS) regression, both assuming a normal error distribution. We tested which of these modeling approaches provided a better fit to our allometric data using Akaike's Information Criterion (AIC) (Table SM2). The AICs of the log-log linear regression models (hereafter, lin- ear models) were compared to those from the NLS models by adding two times the sum of the logged response variables to the linear model AIC value. The AICs for the linearized models were lower than for nonlinear models in at least five of the six study species for each allometric relationship, and so the linearized models were used in all cases. The residuals of these models met the assumption of normality.

Although major axis (MA) regression is recommended for fitting allometric relationships (Warton et al., 2006), we fit linearized models using OLS regression because we were interested in estimating the main and interactive effects of soil type and regeneration niche on allometric relationships, which is more readily accomplished using OLS methods. We report in Table SM3 the slope and elevation parameters with 95\% confidence intervals fit in MA regression using the smatr package (Warton and Ormerod, 2007) in Rstatistical programming software. Type II tests of fixed effects (Fox, 2008) were performed with the car package (Fox et al., 2009) in R. Each allometric model included the three-way interaction between a covariate (DBH or height) and two factors, soil (clayfine loam or sandy loam) and regeneration niche (shade-tolerant, Knema, or light-demanding, Macaranga). A type II test of effects is appropriate in this situation because the result of the test is invariant to the order that the effects are entered into the model (Fox, 2008). Models analyzing interspecific variation in allometry included the four specialist species, and the factor "soil" contrasted congeners of differing soil specialization. Models testing intraspecific variation included both generalist species, and the factor "soil" instead contrasted populations of conspecifics growing distinct soil habitats. Similar models were used to evaluate height safety factor, however, safety factor and its covariate $\mathrm{DBH}$ were not logged since this trait is not typically modeled as a power function.

\subsubsection{Allometric growth models}

We developed species-specific models of height and crown growth rates using diameter growth rate models, parameterized using censuses in 1992, 1997, and 2003 from the Lambir plot, which were then scaled using the fitted parameters for height and crown allometries. Specifically, instantaneous diameter growth rate $(G)$ of a tree was modeled as a power function of diameter (Enquist et al., 1999; Muller-Landau et al., 2006):

$$
G(D)=\mathrm{d} D / \mathrm{d} t=\mathrm{a} D^{\beta}
$$

To find $D$ at given time $(D t)$, we used the approach in MullerLandau et al. (2006) and integrated Equation (1), yielding

$$
D_{t i}=\left(D_{0 i}^{(1-\beta)}+\mathrm{\alpha}(1-\beta) t_{i}\right)^{1 /(1-\beta)}+\varepsilon_{i}
$$

for tree $i$ where $D_{0 i}$ is the initial diameter of the tree, $t$ is intercensus period in years, and $\varepsilon_{i}$ is the deviation of $D_{t i}$ from its predicted value. Since intercensus period varied between trees, we scaled errors with time as in Russo et al. (2007).

To obtain an expression predicting tree height $\left(H_{t}\right)$ given an initial diameter $\left(D_{0}\right)$, we used an approach similar to Coomes et al. (2009) and substituted the expression for $D_{t}$ (Equation (2)) for $D$ in the $H-D$ allometric power function $\left(H=a D^{b}\right)$. Because our goal was prediction, the allometric parameters $a$ and $b$ used in this model were fit using NLS regression, rather than OLS regression, to avoid the error in back-transformation of parameters.

$$
H_{t}=a\left(D_{0}^{(1-\beta)}+\mathrm{a}(1-\beta) t\right)^{b /(1-\beta)}
$$

Instantaneous height growth rate $(\mathrm{d} H / \mathrm{d} t)$ was expressed a function of diameter by using the chain rule to multiply the derivative of the $H-D$ power function $(\mathrm{d} H / \mathrm{d} D)$ by diameter growth rate (Equation (1)) to give

$$
\frac{\mathrm{d} H}{\mathrm{~d} T}=\left(\frac{\mathrm{d} H}{\mathrm{~d} D}\right)\left(\frac{\mathrm{d} D}{\mathrm{~d} t}\right)=\left(a b D^{b-1}\right)\left(\mathrm{a} D^{\beta}\right)
$$


The methods used to derive Equations (3) and (4) were similarly applied to crown area-diameter allometry to yield $C A_{t}$ and $\mathrm{d} C A / \mathrm{d} t$.

The growth-diameter scaling relationship (Equation (2)) for each specialist species and individuals of generalist species on the same soil type were fit using the Neider-Mead simplex search algorithm (Neider and Mead, 1965) as implemented in the function optim in $\mathrm{R}$. We varied initial parameter values to reduce the risk of finding a local maximum.

The longevity of each species was estimated to provide time axes for $H_{t}$ and $C A_{t}$ projections. Longevity was estimated for each species as in Laurance et al. (2004) by dividing the maximum DBH by the median, upper quartile and upper decile of species diameter growth rates and averaging these values. Longevity estimates and parameters used for projection of height and crown area growth are reported in Table SM4.

Our models project growth for trees that maintain average growth rates and allometries throughout life. They thus do not account for variation in growth rates or allometries among individuals (Clark, 2010) and over a tree's life-span, due to, for example, variation in the relationship between height and diameter growth rates between dominant and suppressed trees (Sumida et al., 1997) or temporal autocorrelation of growth rates (Kohyama et al., 2005). Nevertheless, as a tool used to examine mean differences in tree growth and form between soil habitats, our models provide insight into the competitive strategies that tree species exhibit along resource gradients.

\section{Results}

\subsection{Allometric relationships}

The influence of soil type and regeneration niche varied in strength among allometric relationships and between interspecific and intraspecific comparisons. Parameters of the allometric models for each species are presented in Table SM5.

\subsubsection{Height}

Stem $\mathrm{DBH}$, soil specialization, and regeneration niche together explained a large proportion of the variation among soil specialists in stem height $\left(R^{2}=0.88\right.$; Figure $1 \mathrm{a}$ and $\left.\mathrm{b}\right)$, accounting for $5 \%$ more variance than was explained by DBH alone $\left(R^{2}=\right.$ 0.83). The sandy loam specialists, K. galeata and M. lamellata, were each significantly taller at the smallest diameters than the congeneric clay specialists, K. elmeri and M. lamellata $\left(F_{1,156}\right.$ $=55.49, P<0.001$ and $F_{1,77}=4.92, P<0.029$, respectively, Table SM5). The magnitude of this difference was significantly greater for shade-tolerant species than light-demanding species (significant soil by regeneration niche interaction, Table 2). The biological significance of this interaction is evidenced by comparing the predicted stem height of each species at 10 cm DBH: the shade-tolerant sandy loam specialist, K. galeata, is predicted to be $3.3 \mathrm{~m}$ taller than the clay specialist, K. elmeri (9.6 $\mathrm{m}$ vs. $6.3 \mathrm{~m}$ ), while light-demanding sandy loam specialists $M$. lamellata is predicted to be only $1.2 \mathrm{~m}$ taller than clay specialist M. lamellata $(9.8 \mathrm{~m}$ vs. $8.6 \mathrm{~m})$. For the comparison of regeneration niche between clay specialists, the light-demanding species was taller at a given diameter than the shade-tolerant species (M. lamellata vs. K. elemeri, $F_{1,69}=19.45, P<0.001$ ); however, there was no significant difference in the intercepts of the sandy loam specialists M. lamellata and $K$. galeata $\left(F_{1,64}\right.$ $=0.5485, P=0.462$; Table SM5). Neither of the two-way interactions of $\mathrm{DBH}$ with either soil specialization or regeneration niche, nor the three-way interaction between $\mathrm{DBH}$, soil specialization, and regeneration niche was statistically significant (Table 2), indicating that these four species shared a common trajectory of change in height with $\mathrm{DBH}$.
For generalists, stem $\mathrm{DBH}$, regeneration strategy, and soil type together explained a large proportion of the variation in stem height $\left(R^{2}=0.87\right.$; Figure $2 \mathrm{a}$ and $\left.\mathrm{b}\right)$, accounting for $14 \%$ more variation than was explained by $\mathrm{DBH}$ alone $\left(R^{2}\right.$ $=0.73$ ). Soil type had a significant effect on stem height (significant main effect of soil, Table 2), indicating that generalists displayed some intraspecific variation in height allometry in response to variation in belowground resources. In parallel to soil specialists, individuals of K. latericia growing on sandy loam were significantly taller at a given diameter than those on clay-fine loam $\left(F_{1,67}=6.118, P=0.016\right.$, Table SM5). The same trend emerged between $M$. beccariana populations, although the difference was not statistically significant $\left(F_{175}=2.786, P=\right.$ 0.099 , Table SM5).The predicted height at $10 \mathrm{~cm}$ DBH for individuals of K. latericia on sandy loam was 14.0 m versus $12.4 \mathrm{~m}$ on clay-fine loam, and for $M$. beccariana, the predicted height of individuals on sandy loam was $14.8 \mathrm{~m}$ versus $14.3 \mathrm{~m}$ on clayfine loam. The significant interaction between regeneration niche and DBH (Table 2), indicated that these two species have different trajectories of change in height with $\mathrm{DBH}: M$. beccariana was taller than $K$. latericia at small diameters, however, $K$. latericia approached the same height as $M$. beccariana at larger diameters (Table SM5). The amount of within species variation in height allometry due to soil resources did not differ between generalists: neither the two-way interaction involving soil, nor the three-way interaction was significant (Table 2).

\subsubsection{Crown area}

Among soil specialists, $\mathrm{DBH}$, soil specialization, and regeneration niche explained a substantial proportion of variation in crown area $\left(R^{2}=0.74\right.$; Figure $1 \mathrm{c}$ and $\left.\mathrm{d}\right)$ and accounted for $7 \%$ more variance than was explained by DBH alone $\left(R^{2}=\right.$ 0.67). Soil specialization had a significant effect on crown area, but there was a significant interaction between soil specialization and regeneration niche (Table 2) indicating that the soilrelated difference in initial crown area was greater between light-demanding than shadetolerant specialists $(P=0.002$, Table SM5). Among shade-tolerant species, the sandy loam specialist, K. galeata, had a significantly greater intercept than the clay specialist, K. elmeri $\left(F_{1,56}=11.73, P=0.001\right)$, and among light-demanding species, sandy loam specialist $M$. lamellata had a significantly greater intercept than clay specialist, $M$. lamellata $\left(F_{1,77}=8.147, P=0.006\right.$; Table SM5). The significant soil by DBH interaction indicated that the trajectory of change in crown area with DBH varied significantly due to soil specialization (Table 2): clay specialist $K$. elmeri had a significantly larger slope than $K$. galeata $\left(F_{1,56}=6.620, P=0.013\right)$, but the slopes did not differ significantly between light-demanding specialists $M$. lamellata and $M$. lamellata $\left(F_{1,77}=0.6675, P=\right.$ $0.416)$. Consequently, crown area was significantly greater on clay-fine loam than sandy loam over most of the observed diameters among Knema specialists, whereas the opposite was true of Macaranga specialists. In addition to variation due to soil specialization, the crown area-DBH allometry also differed due to regeneration niche (significant regeneration niche-DBH interaction, Table 2). For sandy loam specialists, M. lamellata had a significantly greater slope than $K$. galeata $\left(F_{1,64}=5.570\right.$, $P=0.021)$, but the clay specialists $K$. elmeri and M. lamellata did not differ in slope $\left(F_{1,69}=1.474, P=0.229\right.$; Table SM5). The three-way interaction between $\mathrm{DBH}$, soil specialization, and regeneration niche was not significant (Table 2).

For generalists, $\mathrm{DBH}$, soil type, and regeneration niche together explained a large proportion of variation in crown area allometry $\left(R^{2}=0.80\right.$; Figure $2 \mathrm{c}$ and $\left.\mathrm{d}\right)$, accounting for $4 \%$ more variance than was explained by $\mathrm{DBH}$ alone $\left(R^{2}=0.76\right)$; however, there were no significant effects involving soil type or regeneration niche (Table 2). Thus, little within species variation in crown area allometry was explained by soil type or regeneration niche. 

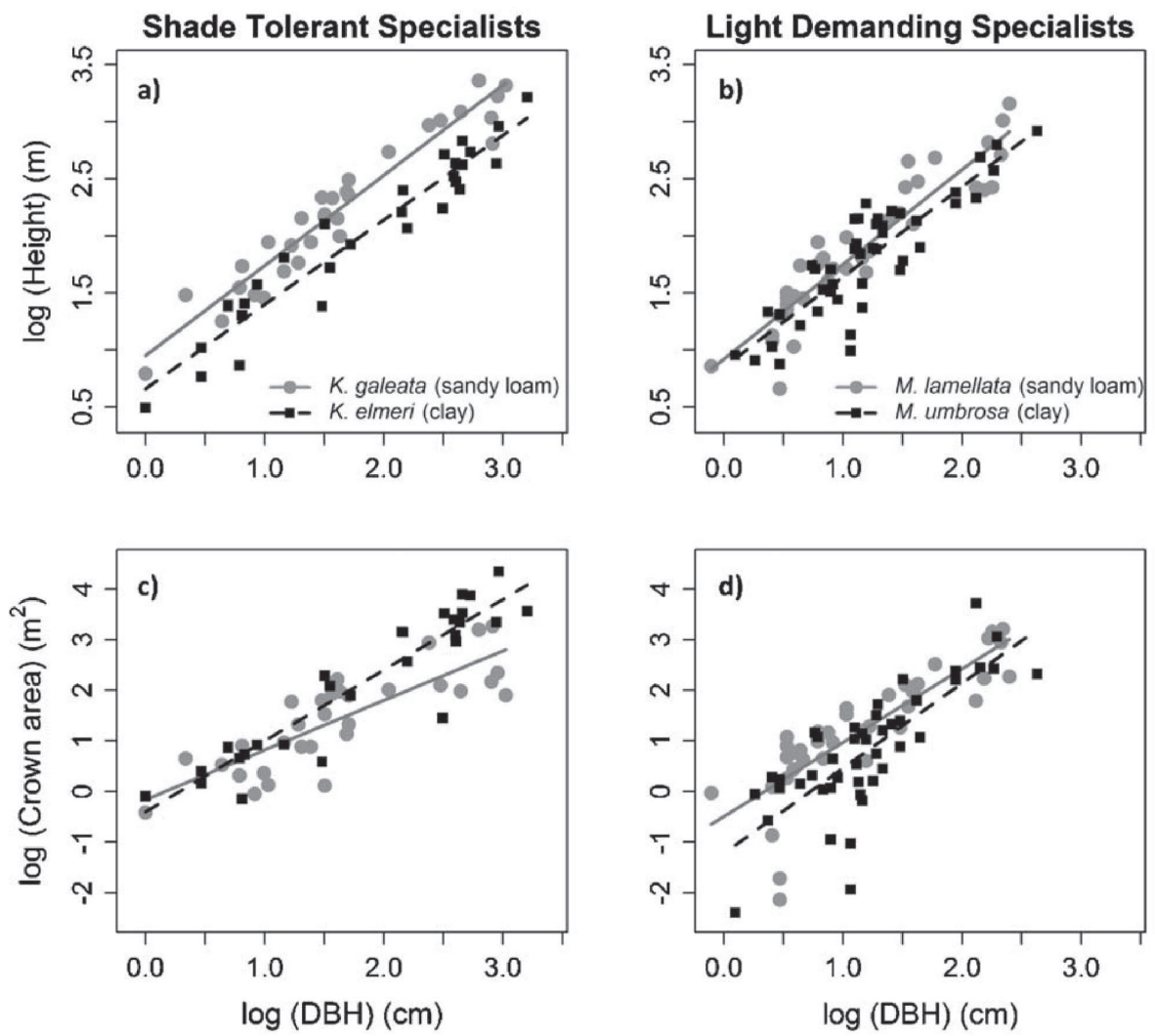

Figure 1. Height-diameter (DBH) and crown area-DBH allometric relationships for four Bornean tree species, including two pairs of congeneric tree species contrasting in soil habitat specialization representing shade-tolerant (Knema) and light-demanding (Macaranga) regeneration niches. Lines were fit using ordinary least squares regression.

Table 2. Type II tests of effects for linearized power function models of height, crown area, and crown depth allometry. Each model included a covariate of size (DBH or height) and two factors, soil (sandy loam or clay) and regeneration niche (regen; light-demanding or shade-tolerant), with all interactions. In "Specialist" models, the factor "soil" contrasts related species of differing soil specializations; in "Generalist" models, "soil" contrasts individuals of the same species on different soil types. Bold typeface highlights statistically significant factors.

\begin{tabular}{|c|c|c|c|c|c|}
\hline \multirow[t]{2}{*}{ Trait } & \multirow[t]{2}{*}{ Effects } & \multicolumn{2}{|l|}{ Specialists } & \multicolumn{2}{|c|}{ Generalists } \\
\hline & & $F_{1,733}$ & $P$ & $F_{7,142}$ & $P$ \\
\hline Height & $\begin{array}{l}\text { DBH } \\
\text { Soil } \\
\text { Regen } \\
\text { DBH } \times \text { soil } \\
\text { DBH } \times \text { regen } \\
\text { Soil } \times \text { regen } \\
\text { DBH } \times \text { soil } \times \text { regen }\end{array}$ & $\begin{array}{l}921.4 \\
35.89 \\
14.17 \\
0.7370 \\
0.9930 \\
7.719 \\
0.0003\end{array}$ & $\begin{array}{r}<0.001 \\
<0.001 \\
<0.001 \\
0.392 \\
0.321 \\
\mathbf{0 . 0 0 6} \\
0.985\end{array}$ & $\begin{array}{c}543.1 \\
8.993 \\
39.67 \\
0.2107 \\
0.12 .35 \\
0.3747 \\
0.0899\end{array}$ & $\begin{array}{r}<0.001 \\
0.003 \\
<0.001 \\
0.648 \\
<0.001 \\
0.547 \\
0.765\end{array}$ \\
\hline Crown depth & $\begin{array}{l}\text { Height } \\
\text { Soil } \\
\text { Regen } \\
\text { Height } \times \text { soil } \\
\text { Height } \times \text { regen } \\
\text { Soil } \times \text { regen } \\
\text { Height } \times \text { soil } \times \text { regen }\end{array}$ & $\begin{array}{l}92.05 \\
7.323 \\
16.57 \\
1.708 \\
0.0065 \\
6.134 \\
2.465\end{array}$ & $\begin{array}{r}<0.001 \\
\mathbf{0 . 0 0 8} \\
<0.001 \\
0.193 \\
0.936 \\
\mathbf{0 . 0 1 5} \\
0.119\end{array}$ & $\begin{array}{c}141.7 \\
1.089 \\
31.33 \\
1.515 \\
6.502 \\
0.0022 \\
1.427\end{array}$ & $\begin{array}{r}<0.001 \\
0.298 \\
<0.001 \\
0.220 \\
\mathbf{0 . 0 1 1} \\
0.962 \\
0.234\end{array}$ \\
\hline Safety factor & $\begin{array}{l}\text { DBH } \\
\text { Soil } \\
\text { Regen } \\
\text { DBH } \times \text { soil } \\
\text { DBH } \times \text { regen } \\
\text { Soil } \times \text { regen } \\
\text { DBH } \times \text { soil } \times \text { regen }\end{array}$ & $\begin{array}{l}11.49 \\
26.50 \\
8.879 \\
0.0338 \\
2.076 \\
9.703 \\
0.0763 \\
\end{array}$ & $\begin{array}{r}\mathbf{0 . 0 0 1} \\
<0.001 \\
\mathbf{0 . 0 0 3} \\
0.854 \\
0.152 \\
\mathbf{0 . 0 0 2} \\
0.783 \\
\end{array}$ & $\begin{array}{c}0.9858 \\
5.903 \\
30.49 \\
0.4423 \\
13.72 \\
0.1395 \\
0.0005 \\
\end{array}$ & $\begin{array}{r}0.322 \\
\mathbf{0 . 0 1 6} \\
<0.001 \\
0.507 \\
<0.001 \\
0.709 \\
0.983 \\
\end{array}$ \\
\hline
\end{tabular}



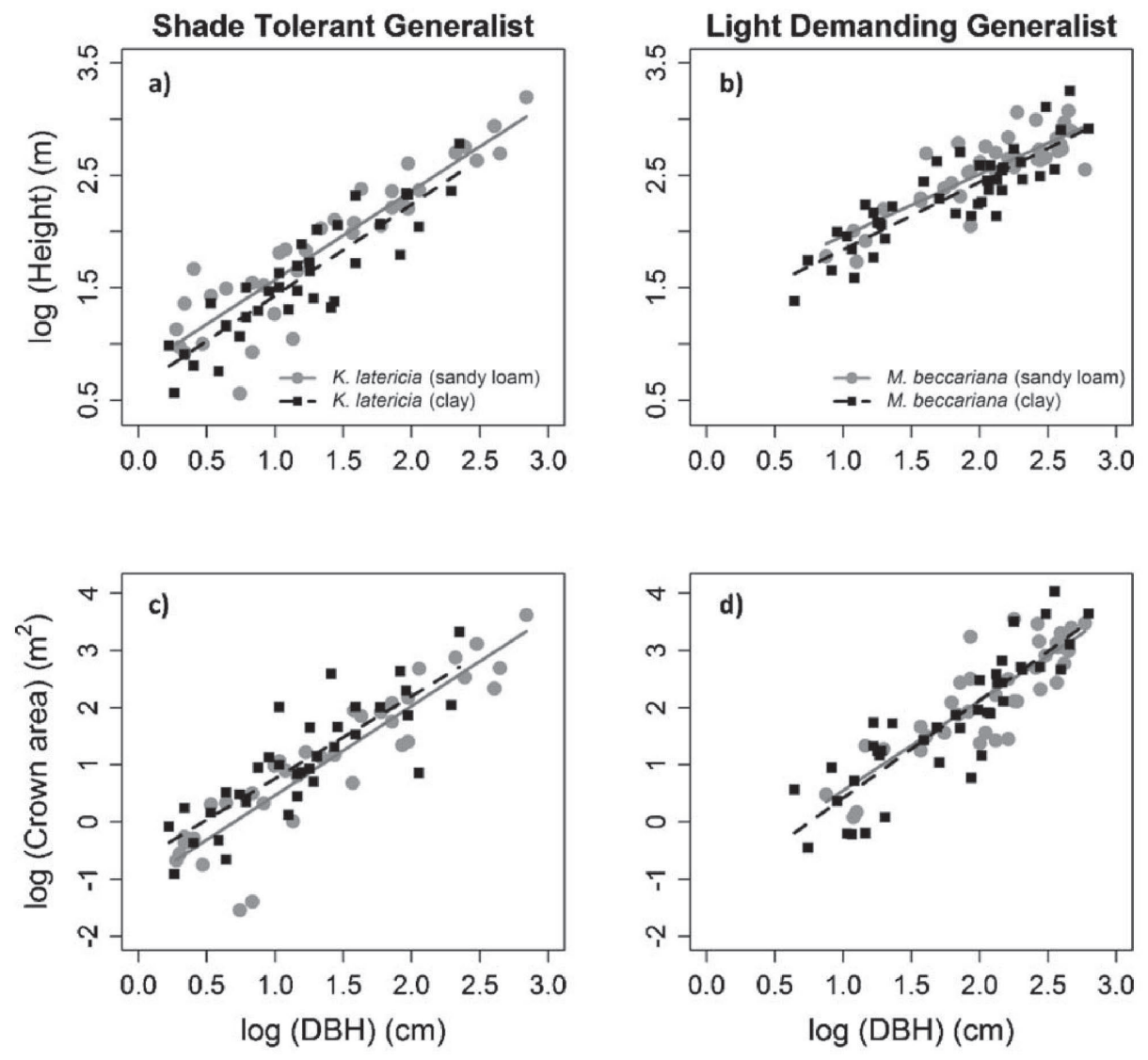

Figure 2. Height-diameter (DBH) and crown area-DBH allometric relationships for Bornean tree species, including two generalist tree species that were sampled on both sandy loam and clay-fine loam habitats and represented shade-tolerant (K. latericia) and light-demanding ( $M$. beccariana) regeneration niches. Lines were fit using ordinary least squares regression.

\subsubsection{Crown depth}

Among soil specialist species, height, soil specialization, and regeneration niche accounted for approximately half of the observed variation in crown depth $\left(R^{2}=0.49\right.$; Figure $3 \mathrm{a}$ and $\left.\mathrm{b}\right)$, accounting for $13 \%$ more variance than was explained by height alone $\left(R^{2}=0.36\right)$. The interaction between soil specialization and regeneration niche was significant (Table 2): in the shadetolerant genus, clay specialist K. elmeri had significantly deeper crowns at small heights than sandy loam specialist, $K$. galeata $\left(F_{1.56}=20.04, P<0.001\right)$, but initial crown depth did not differ between lightdemanding specialists $\left(F_{1,77}=0.0445, P=0.833\right.$, Table SM5). Neither of the two-way interactions of height with soil specialization or regeneration niche, nor the three-way interaction, was statistically significant (Table 2), indicating a shared trajectory of change in crown depth with height.

Height, soil, and regeneration niche explained a similar proportion of variation in crown depth among generalists as they did among soil specialists $\left(R^{2}=0.49\right.$; Figure $3 \mathrm{c}$ and $\left.\mathrm{d}\right)$, accounting for $15 \%$ more variation than was explained by height alone $\left(R^{2}=0.44\right)$. Significant intraspecific variation in crown depth due to soil resources was not observed in either generalist, as neither the main effect of soil type nor its interactions with height or regeneration niche was significant (Table 2). The significant interaction between height and regeneration niche (Table 2) arose because crown depth increased more rapidly with height in $M$. beccariana than $K$. latericia $(P<0.001$, Table SM5).

\subsubsection{Height safety factor}

For soil specialists, DBH, soil, and regeneration niche explained a small proportion of the variation in height safety factor $\left(R^{2}=0.24\right.$; Figure 4$)$. The height safety factor declined significantly with DBH among soil specialists (Table 2, SM5). In addition, soil specialization had a significant effect on mechanical stability: the sandy loam specialists, K. galeata and $M$. lamellata, both grew closer to their critical heights than did the clay specialist congeners, K. elmeri and M. lamellata (Figure 4). A significant interaction between soil and regeneration niche (Table 2) arose because this difference was significant between Knema specialists $\left(F_{156}=43.71, P<0.001\right)$ but not Macaranga specialists $\left(F_{1,77}=2.710, P=0.104\right)$. No interaction with $\mathrm{DBH}$ was significant; thus, all four species showed parallel changes in height safety factor with increasing diameter.

For generalists, a slightly larger fraction of variation in safety factor was explained by $\mathrm{DBH}$, soil, and regeneration niche $\left(R^{2}=0.29\right.$; Figure 4$)$. For generalists, soil resources had a significant effect on the height safety factor (Table 2): individuals on sandy loam grew closer to their buckling height on average than conspecifics on clay-fine loam (Table SM5), but this difference was not statistically significant within either the shade-tolerant generalist, $K$. latericia $\left(F_{1,67}=3.111, P\right.$ $=0.026)$ or light-demanding generalist, $M$. beccariana $\left(F_{1,75}=\right.$ $3.295, P=0.0735)$. A significant interaction between $\mathrm{DBH}^{1}$ and regeneration niche Table 2) arose because height safety factor decreased significantly with size in $M$. beccariana $\left(F_{1,75}=\right.$ $5.865, P=0.018$ ) and $K$. latericia (FI $, 67=7.256, P=0.009$, Table SM5). Neither the two-way interaction between regeneration niche and soil nor the three-way interaction was significant, indicating that the amount of within species variation in height safety factor due to soil resources did not vary between genera. 

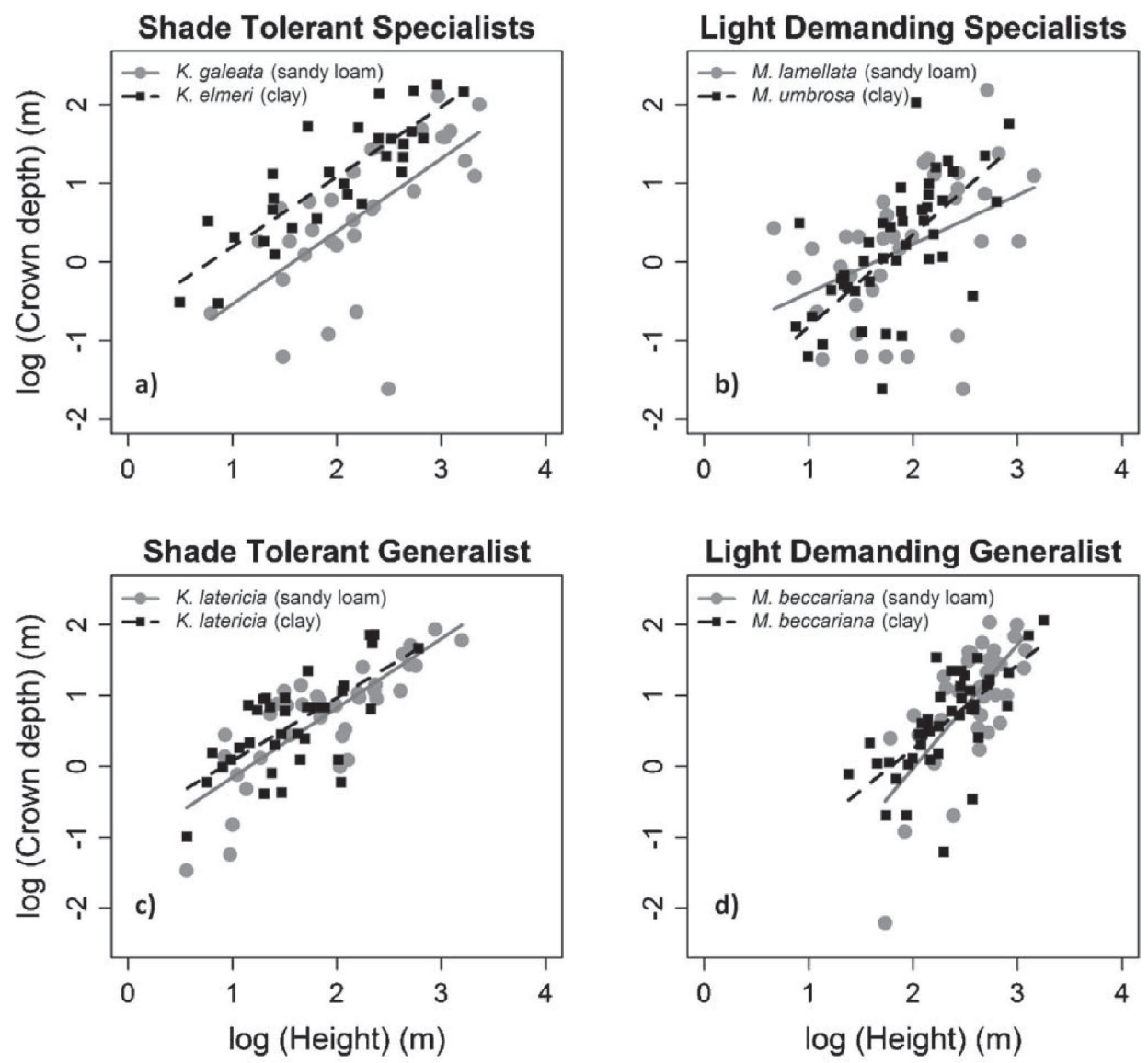

Figure 3. Crown depth-height allometry allometric relationships for six Bornean tree species including (a and b) two pairs of congeneric tree species contrasting in soil habitat specialization (c and d) and two generalists sampled on both sandy loam and clay-fine loam habitats. Species represented shade-tolerant (Клета) and light-demanding (Macaranga) regeneration niches. Lines were fit using ordinary least squares regression.

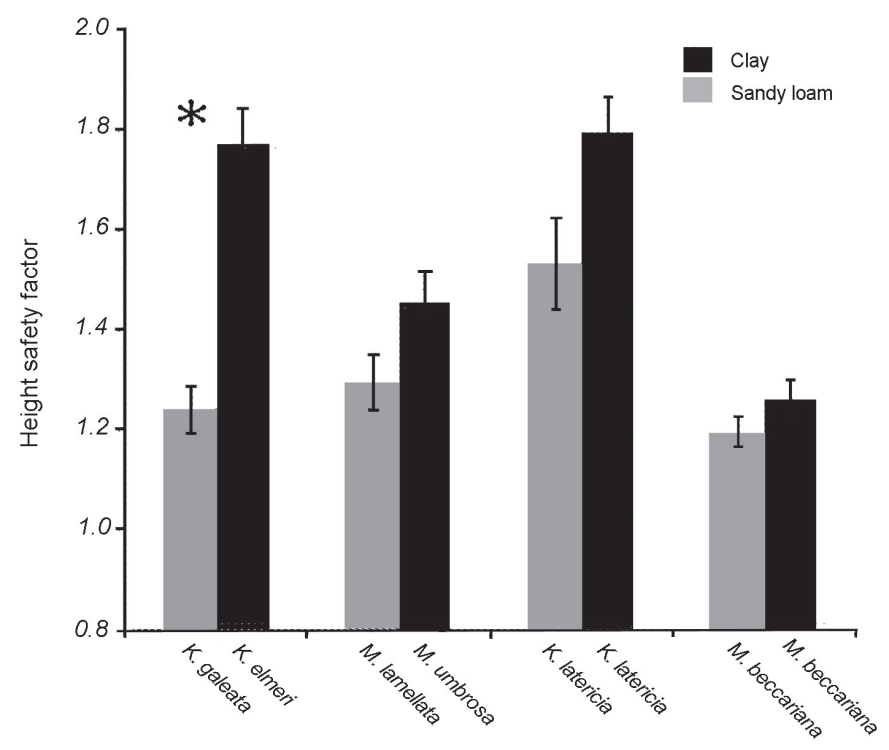

Figure 4. Interspecific and intraspecific comparisons of tree height safety factor for six Bornean tree species, including two pairs of congeneric tree species contrasting in soil habitat specialization and two generalists sampled on both sandy loam and clay-fine loam habitats. Species represented shade-tolerant (Knema) and light-demanding (Macaranga) regeneration niches. The asterisk represents a significant difference in height safety factor between soil types $P<0.05$.

\subsection{Dynamic allometric models}

We projected stem height and crown area growth over time periods corresponding to an estimate of the lifespan of each tree species (specialists) and populations on each soil type (generalists) to predict the effect of soil resources on allometric growth rates (Table SM5, Figure 5).

Overall, models of allometric height growth for specialists and generalists (Figure 5a-d) supported our prediction that trees on the more fertile, moister clay-fine loam soil would have faster height growth rates than trees of the same age on sandy loam. Although sandy loam specialists were taller at younger ages, they were eventually surpassed in height by clay specialists (Figure $5 \mathrm{a}$ and $\mathrm{b}$ ). In both pairs of specialists, our models showed that clay specialists would overtake sandy loam specialists in height after about fifty years. Among Knema specialists, both species grew to approximately the same maximum height, but the shorter-lived, clay specialist, $K$. elmeri, reached this height more quickly than did the longer-lived, sandy loam specialist, K. galeata. Macaranga specialists were similar in height over the lifespan of the sandy loam specialist $M$. lamellata, but with a longer lifespan, the clay specialist $M$. lamellata reached a larger maximum height. A similar pattern held for generalists: individuals on clay-fine loam were taller than those on sandy loam at all ages except for the earliest (Figure 5c and d). Our models of generalists showed that populations on clay-fine loam would overtake those on sandy loam within 25 years in K. latericia and within 5 years in $M$. beccariana. The projected difference in height between conspecifics of the same age on contrasting soil types was greater 

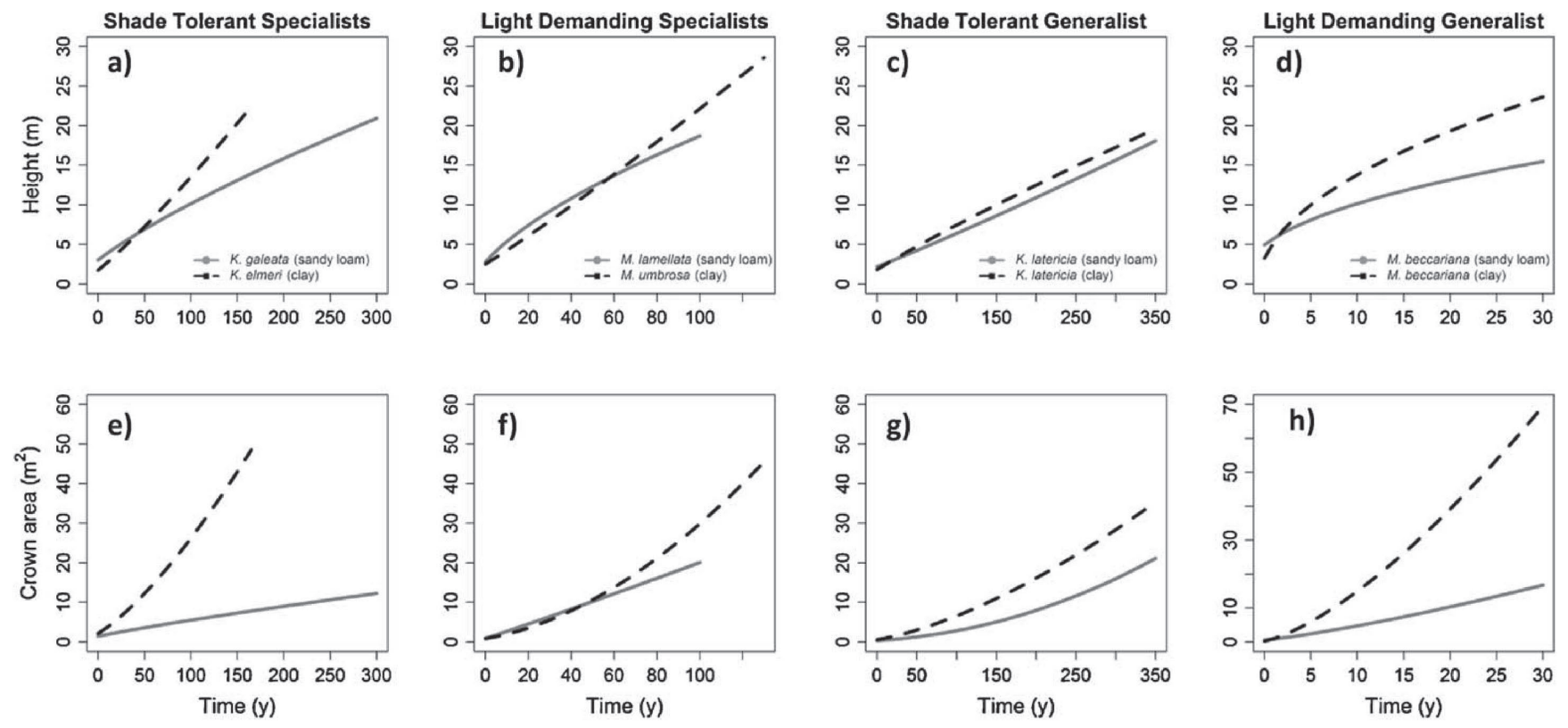

Figure 5. Model projections of stem height and crown area with time for six Bornean tree species including two pairs of congeneric tree species contrasting in soil habitat specialization and two generalists sampled on both sandy loam and clay-fine loam habitats. Species represented shade-tolerant (Knеma) and light-demanding (Macaranga) regeneration niches. The integrated diameter growth rate and allometric height-DBH and crown area-DBH parameters were used to model stem height and crown area growth over the estimated lifespan of each species. See Section 2 for details of model development and fitting. Note changes in vertical axis scales.

in $M$. beccariana than in K. latericia, supporting our prediction that lightdemanding species would exhibit greater intraspecific variation in aboveground growth rate due to soil resources than shade-tolerant species.

Models of crown area growth (Figure 5e-h) predicted that trees growing on clay-fine loam soil generally would exhibit greater crown area at a given age than trees on sandy loam, consistent with our prediction. Models of specialists demonstrated that the crown of clay specialist $K$. elmeri was larger at $1 \mathrm{~cm} \mathrm{DBH}$, grew more rapidly over time, and reached a larger maximum area than sandy loam specialist, K. galeata (Figure 5e). In contrast, Macaranga specialists shared a similar crown growth trajectory for their first fifty years of growth, but clay specialist $M$. lamellata eventually surpassed sandy loam specialist $M$. lamellata and reached a larger maximum crown area (Figure 5f). Models for both generalists showed that conspecifics had approximately the same initial crown area regardless of soil type, but populations on clay-fine loam spread their crowns more quickly and attained a greater maximum crown area than those on sandy loam (Figure $5 \mathrm{~g}$ and $\mathrm{h}$ ). Models projected greater differences between sandy loam and clay-fine loam populations in crown area with age in the light-demanding generalist $M$. beccariana than in the shade-tolerant generalist K. latericia, implying greater within species variation in crown growth due to soil resources.

Models predicting the change in height and crown area growth rates with DBH varied in shape among species (Figure 6). For Knema specialists, both height and crown area growth rates were more similar at initial diameters but diverged slowly with increasing diameter, with K. elmeri increasing and K. galeata decreasing slightly in growth rate (Figure 6a and e). Between Macaranga specialists, $M$. lamellata had higher initial height and crown area growth rates, but was overtaken by $M$. lamellata in both by ca. $3 \mathrm{~cm} \mathrm{DBH}$ (Figure $6 \mathrm{~b}$ and f). Individuals of $K$. latericia on the two soil types differed only subtly in growth rates. In height growth rate (Figure 6c), individuals on clay-fine loam grew faster initially but were surpassed in growth rate by sandy loam individuals by $11 \mathrm{~cm} \mathrm{DBH}$. Crown area models demonstrated that individuals of $K$. latericia on both soil types also have similar growth rate across all diam- eters (Figure $6 \mathrm{~g}$ ). The height growth rate in M. beccariana decreased exponentially over a range of diameters (Figure 6d), whereas the crown area curve was an increasing function (Figure $6 \mathrm{~h}$ ). In both comparisons, the individuals on clay-fine loam grew faster than those on sandy loam.

\section{Discussion}

Tree stems and crowns play key roles in competitive interactions in forests since they display light-harvesting organs (leaves) and, in doing so, preempt light from smaller individuals (Weiner, 1990). Because trees should be under selection to maximize growth rate, given survival (Givnish, 1988), tree species may evolve different height- and crown-growth strategies in response to resource availability, and there is abundant evidence that a diversity of such strategies exists (e.g., Halle et al., 1978; Horn, 1971; Kohyama and Hotta, 1990; Poorter et al., 2006). Aboveground growth can, however, be limited by belowground resource availability (Bungard et al., 2002; Burslem et al., 1996; Grubb et al., 1996; Latham, 1992; Turner, 1991), but the nature of this limitation is still debated (Coomes and Grubb, 1998). Competition for light maybecome more intense with increases in belowground resources, favoring tree species with faster aboveground growth rates on soil types with greater, relative to lesser, resource supply rates (Tilman, 1988). Overall, our height and crown growth models were consistent with this mode of competition: in the six Bornean trees species examined, soil-related habitat variation influenced both the overall rates of growth in height and crown area and their rates of change with tree size. Species specializing on the moister, more fertile clay soil extended their stems and crowns more rapidly than species specializing on the well-drained, less fertile sandy loam soil. Our results are consistent with other observations (e.g., Coomes and Allen, 2007) that soil resources, in addition to light, can affect aboveground competition with neighboring trees. In addition, understory light availability is lower on the clay than sandy loam soil (Russo et al., 2010; S.E. Russo, unpub. data). This difference is likely a result of the greater leaf areas of canopy trees on clay (Ash- 

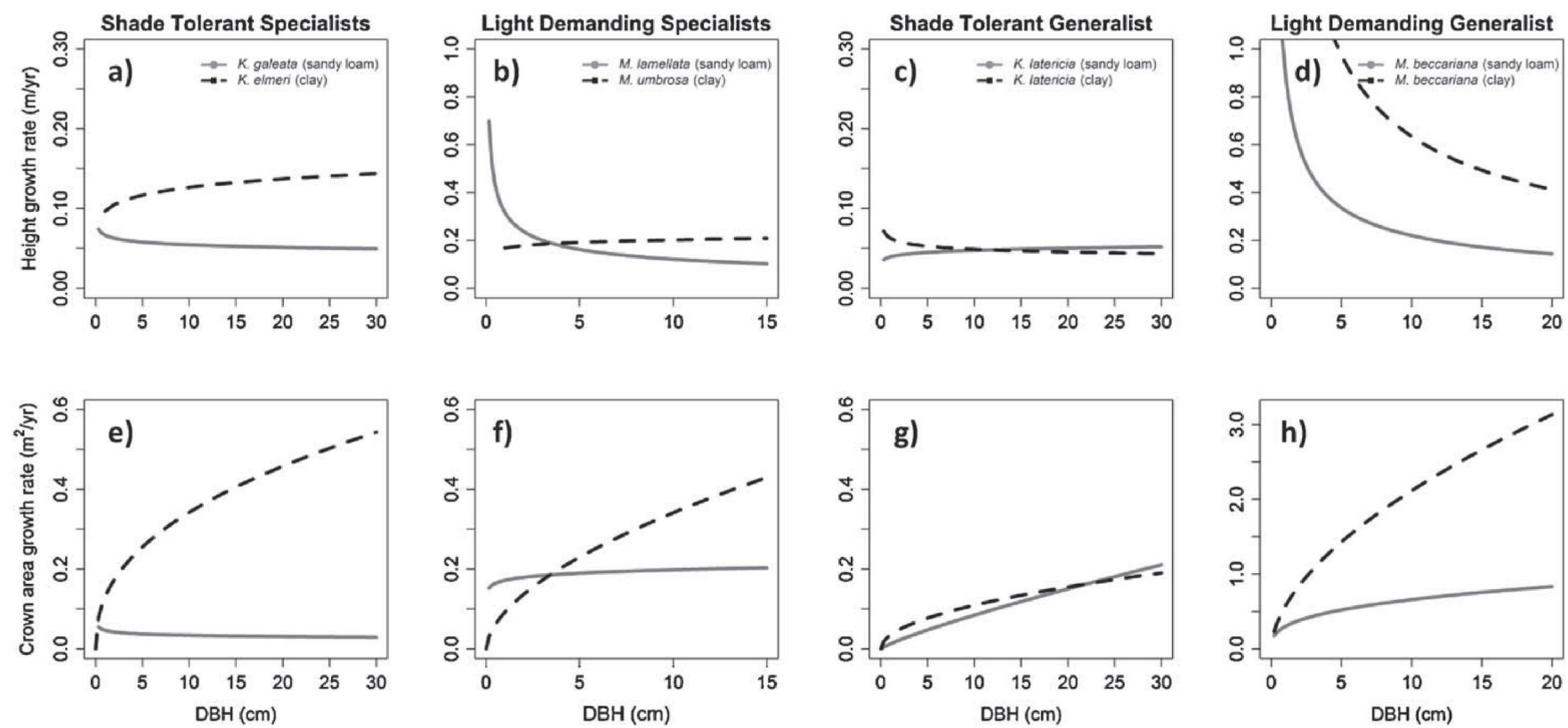

Figure 6. Model projections of stem height and crown area growth rate over the range of diameters observed in six Bornean tree species including two pairs of congeneric tree species contrasting in soil habitat specialization and two generalists sampled on both sandy loam and clay-fine loam habitats. Species represented shade-tolerant (Knema) and light-demanding (Macaranga) regeneration niches. See the Methods section for details of model development and fitting.

ton, 1964; Ashton and Hall, 1992) and suggests that competition for light is more intense there than in the understory of forest on the sandy loam soil. The divergent allometric growth strategies that we found between soil specialists indicate that these subcanopy tree species respond to this greater competitive effect (sensu Goldberg, 1996) on the clay-fine loam soil with increased growth rates in height and canopy area. Additionally, seedling reciprocal transplant experiments at Lambir indicate that it is unlikely that these patterns are only a symptom of shifts in soil resource availability, but rather reflect species-specific allometric growth strategies, because the increase in growth rate for sandy loam specialists planted on clay soil is less than the decrease in growth rate of the clay specialists on sandy loam (Palmiotto et al., 2004). The competitive outcomes predicted by our models support the idea that resource competition theory (Tilman, 1988) provides a reasonable mechanism to explain how specialists of sandy loam may be competitively excluded from clay-fine loam, which would contribute to the dramatic patterns of soil-related floristic variation observed at Lambir. Aboveground competition between temperate tree species, as inferred by height growth rates and mediated by light, has also been linked to differences in species distribution between habitats in two biogeoclimatic zones in North America (Wang and Kimmins, 2002). Our findings provide further evidence of the importance for understanding forest community structure of feedbacks involving aboveand belowground resources that are both a cause and a consequence of the structural and functional features of the forest.

\subsection{Soil-related differences in height and crown allometries and growth}

Our height growth models projected that clay specialists would be taller than sandy loam specialists at the same age for most of their lifespans. Sandy loam specialists were, however, found to be taller at the youngest ages, but would be surpassed in height by clay specialists after approximately fifty years of growth. This result is inconsistent with trenching experiments in tropical forests that resulted in increased aboveground growth in seedlings experiencing reduced belowground competition (Coomes and Grubb, 1998; Lewis and Tanner,
2000).The opposite trend may have been observed at Lambir because understory light availability is greater on sandy loam relative to clay soil (Russo et al., 2010). In the depths of the understory, tree seedlings are likely to be more limited by light than soil resources (Palmiotto et al., 2004; Coomes and Allen, 2007). Although we lack information on the vertical gradient in light availability at Lambir, this soil-related difference in understory insolation likely dissipates moving up vertically through the canopy. Thus, due to greater access to light, seedlings of sandy loam specialists may achieve initially faster growth rates than do those of clay specialists, until juvenile clay specialists achieve a stratum in the canopy with enough light for increased soil nutrients to matter, enabling a competitive advantage.

Consistent with the interspecific modeling results, only at the youngest ages did our models predict populations of generalists to be taller on sandy loam than on clay-fine loam. Furthermore, our models predicted trees from clay-fine loam-soil populations to have larger crowns over each species' lifespan than in sandy loam populations. Similar models of sapling height growth in a temperate rainforest in New Zealand also predicted soil-related intraspecific variation, with tree populations growing faster on more fertile alluvial soil, relative to conspecifics on less fertile terrace soils, despite lower understory light on the alluvial soil (Coomes et al., 2009). Intraspecific differences in height and crown growth rates for generalists were greater in the light-demanding $M$. beccariana than the shade-tolerant $K$. latericia. This result is consistent with observations that fast-growing, light-demanding species generally exhibit greater plasticity in growth responses to variation in both above- and belowground resources (Bazzaz, 1979; Valladares et al., 2000).

While comparisons between height-and crown-allometric growth rates of trees on contrasting soils were consistent with our competition-based predictions, comparisons of static allometric scaling relationships of height and crown dimensions with diameter were not. Forest stature is commonly viewed as a measure of site quality, but contrary to this view, the tallest forests in a region are not always found on the most nutrient-rich, moist soils (Ashton and Hall, 1992; Grubb, 1989). Our results are consistent with these observations in that al- 
though our study species exhibited consistent patterns of soilrelated variation in height-diameter scaling, the overarching trend was contrary to competition-based predictions, since sandy loam specialists generally had higher allometric intercepts than did clay specialists. In reconciling the findings that model-based dynamic growth, but not static, allometries were consistent with our predictions, an important consideration is that trees at a given diameter are older on sandy loam than on clay-fine loam soil, due to the slower diameter growth and lower mortality rates there (Russo et al., 2005). Thus, while trees of sandy loam specialists and generalists were largely found to be taller and to have wider crowns at a given diameter, once time is accounted for, these differences in allometric scaling relationships are insufficient to outweigh the differences in diameter growth rate, causing clay specialists to be taller and have wider crowns than sandy loam competitors of the same age. Allometric scaling relationships are static measures of tree structure and do not fully represent a tree's ability to compete for resources over its lifetime. Differences in competitive interactions cannot be inferred only from allometric scaling relationships because the allometries must be scaled to account for tree growth rates. Thus, models of allometric growth, rather than static allometric scaling relationships, provide a better metric for testing hypotheses about possible competitive outcomes.

There was little statisticallysignificant soil-related intra-specific variation in the static height and crown allometries of either generalist. Nevertheless, at least some of the interspecific differences in allometric growth between soil specialists may be due to plastic responses or genotypic variation associated with the local environment, in addition to adaptive variation. Variation in growth rates between conspecifics does not necessarily translate to differences in population dynamics (Yamada et al., 2007). Nevertheless, whether a result of adaptive or plastic responses, our results suggest that trees growing on a common soil-defined habitat conform to similar competitive strategies.

Significant inter- and intraspecific differences in height allometry were restricted to allometric coefficients, or linear model intercepts, supporting prior observations that allometric exponents, or linear model slopes, are relatively consistent (King, 1990a; Kohyama, 1987; Kohyama ancillotta, 1990), although this has not been observed among tree species in New Zealand (Russo et al., 2007). Thus, species differ in average height at a given diameter rather than in trajectory of height growth with diameter. Predicted differences in stem height between soil specialists at $10 \mathrm{em} \mathrm{DBH}$ range from 1.2 $\mathrm{m}$ (Macaranga spp.) to $3.3 \mathrm{~m}$ (Knema spp.), which is biologically important considering that light availability increases exponentially with elevation in the canopy (Yocla, 1974). Differences in allometry between soil habitats tended to be more pronounced in the shade-tolerant genus, which might be because Macaranga regenerates in brighter environments and canopy openings (Davies et al., 1998), and so may be less affected by the differences in understory light between the soil types under a closed canopy. Although we examined saplings and adult trees, our findings are consistent with previous studies in other Bornean mixed dipterocarp forests that have found significant soil-related inter-and intraspecific variation in the aboveground allometries of seedlings growing in heath versus peat swamp forest species in Borneo (Nishimura and Suzuki, 2001) and have observed stand-level variation in height-diameter allometries between lowland forests differing in soil mineral nutrient and water content (Ashton and Hall, 1992; Grubb, 1989). Although we found significant soil-related differences in crown allometry, predictions of crown architecture based on current light environment (i.e., Horn, 1971) were not realized. Others propose that crown architecture does not conform to geometry expected in its current light environment (Poorter et al., 2003), and suggest instead that differences in crown geometry reflect primarily the regeneration niche (Kohyama, 1987) or adult stature (Kohyama et al., 2003) of a species or the plasticity of crown growth in a heterogeneous light environment (Dietze et: al., 2008).

\subsection{Soil-related differences in height safety factor}

Not only were trees taller at a given diameter on sandy loam, they also grew closer to their critical buckling height than did trees on clay-fine loam soil. Both sandy loam specialists had greater wood density than their clay soil congeners. Although increased wood density itself reduces tree mechanical stability by increasing the force of gravity acting on the stem column, the associated increase in Young's modulus of elasticity counteracts the destabilizing effect of increased density and causes the critical buckling height of a tree to increase (Fournier et al., 2006; van Gelder et al., 2006). For this reason, trees with greater wood densities may grow taller at a given diameter without buckling under their own weight, relative to similarly proportioned trees with lower wood density. However, after accounting for the denser wood ofsandy loam specialists, we found that although they had a higher theoretical buckling height than related clay specialists, sandy loam specialists still grew closer to their critical height. Although trees are known to compete for light by increasing their height-to-diameter ratio in response to lateral shading (Henry and Thomas, 2002), trees on the better-lit sandy loam may nevertheless grow closer to their buckling height than trees on clay-fine loam if they possess a superior belowground support system. Trees on well-drained soils have been found to extend their roots to greater depths than trees on poorly-drained soils, thereby reducing the risk of mechanical toppling (Fraser, 1962).

The more slender stem architecture exhibited by trees on sandy loam may also be related to their lower growth and mortality rates. In a study of the allometry of adult-stature Bornean trees, species with slower diameter growth rates had significantly thinner stems at a given height on average than fast-growing species (Sterck et al., 2001), which accords with our findings that specialists and populations of generalists on sandy loam grew closer to their critical height and were taller at a given diameter than the faster-growing trees on clay-fine loam. It has been hypothesized that slower-growing tree species having skinnier stems with denser wood reduce respiratory costs associated with surface area of the cambia, despite the fact that that thicker stems of equal strength can be constructed from softer wood for less total carbon (Anten and Schieving, 2010; Larjavaraara and Muller-Landau, 2010). When we compared the metrics of trunk strength and construction costs used in Larjavaraara and Muller-Landau (2010) between soil specialists, we found that, at the same height, sandy loam specialists had weaker, more cheaply made stems than clay specialists, despite their greater wood density (results not shown). Dense-wooded, but thin stems may therefore promote the survival of sandy loam specialists by minimizing carbon allocation to trunk construction and respiration, in addition to affording increased pathogen protection (e.g., Alvarez-Clare and Kitajima, 2007).

Additionally, differences in stem construction between soil habitats have implications for the improved approximation of forest carbon stocks. With programs such as Reducing Emissions from Deforestation and Degradation (REDO) regarded as key to the mitigation of global climate change (UNFCC, 2008), accurate estimation of carbon sequestration is an increasingly important aspect of forest management. In the six species examined here, soil habitat accounted for significant variation in two important components of forest biomass estimates: wood density, a known determinant of spatial biomass distributions (Baker et al., 2004), and allometric parameters, which contribute a large proportion of error to aboveground 
biomass estimates (Chave et al., 2004). Therefore, analysis of an expanded suite of species is necessary to determine the scale and extent these patterns of soil-related patterns in tree architecture and, consequently, if soil type should be considered as a factor in models predicting forest biomass.

\section{Conclusions}

Characterizing the allometric growth strategies of trees along resource gradients as they compete for a better light environment provides insight into the mechanisms that cause species composition to vary among forest types. Our study is the first to examine variation in allometry and to model tree and crown growth strategies of adult-stature tropical trees with respect to belowground resources to test one possible mechanism by which soil-specific tree species distributions may arise. The competitive outcomes predicted by our models suggest that resource competition theory (Tilman, 1988) provides a viable mechanism that can at least partly explain how tree species characteristic of soils with low resource supply rates may be competitively excluded from more resourcerich soil types. Allometric scaling relationships and diameter growth models parameterized for more tree species and from other forests should be used to test the generality of our findings. Our results point to the importance of adaptive and plastic responses to both above and belowground resource availability in determining the allometric growth responses of trees and suggest that this diversity of responses has the potential to contribute to the coexistence of tree species by competitionbased trade-off mechanisms (e.g., Hurtt: and PaGlia, 1995; PaGlia and Rees, 1998; Tilman, 1988) and by variation of allometric growth among individuals (Clark, 2010).

Acknowledgments - We are grateful to the Sarawak Forestry Corporation and Sarawak Forestry Department for permitting us to conduct research in Lambir Hills National Park. The 52-ha forest dynamics plot at Lambir is operated jointly by the Forest Department of Sarawak, Malaysia, Harvard University, USA (under NSF awards DB-9107247 and DEB-9629601 to P.S. Ashton), Osaka City University, Japan (under Monbusho grant 06041094 to T. Yamakura, 08NP0901 to S. Tamura and 09NP0901 to S. Sasaki). Funding was provided by the NSF-funded Research for Undergraduates in Theoretical Ecology (RUTE) program at the University of Nebraska-Lincoln, USA (DUE0531920), a Sigma Xi Grant in Aid of Undergraduate Research, University of Nebraska-Lincoln School of Biological Sciences Undergraduate Special Funds, and the Functional Traits Project of the Center for Tropical Forest Science Arnold Arboretum Asia Program. We thank also David King and Chad Brassil for their constructive comments on previous versions of this manuscript and our field assistants JugokUkat and Lela Ali for their invaluable help and expertise.

Appendix A. Supplementary data is presented following the References.

\section{References}

Ashton, P.S., 1964. Ecological Studies in the Mixed Dipterocarp Forests of Brunei State. Clarenden Press, Oxford.

Anten, N.P.R., Schieving, F., 2010. The role of wood mass density and mechanical constraints in the economy of tree architecture. American Naturalist $175,250-260$

Ashton, P.S., Hall, P., 1992. Comparisons of structure among mixed dipterocarp forests of north-western Borneo. Journal of Ecology 80, 459-481.

Alvarez-Clare, S., Kitajima, K., 2007. Physical defence traits enhance seedlingsurvival of neotropical tree species. Functional Ecology 21, 1,044-1,054.

Baillie, I.E., Ashton, P.S., Chin, S.P., Davies, S.J., Palmiotto, P.A., Russo, S.E., Tan, S., 2006. Spatial associations of humus, nutrients, and soils in mixed dipterocarp forest at Lambir, Sarawak, Malaysian Borneo. Journal of Tropical Ecology 22, 543-553.

Baker, T.R, Phillips, O.L., Malhi, Y., Almeidas, S., Arroyo, L., Di Fiore, A., Erwin, T., Killeen, T.J., Laurance, S.G., Laurance, W.F., Lewis, S.L., Lloyd, J., Moteagudo, A., Neil, D., Patino, S., Pitman, N.E.A., Natalino, M., Silva, J., Vasquez Martinez, R., 2004. Variation in wood density determines spatial patterns in Amazonian forest biomass. Global Change Biology 10, 545-562.

Bazzaz, E.A., 1979. The physiological ecology of plant succession. Annual Re- view of Ecology and Systematics 10, 351-371

Broadfoot, W.M., 1969. Problems in relating soil to site index for southern hardwoods. Forest Science 15, 354-364.

Bungard, R.A., Zipperlen, S.A., Press, M.E., Scholes, J.D., 2002. The influence of nutrients on growth and photosynthesis of seedlings of two rainforest dipterocarp species. Functional Plant Biology 29, 505-515.

Burslem, D.F.R.P., Grubb, P.J., Turner, I.M., 1996. Responses to simulated drought and elevated nutrient supply among shade-tolerant tree seedlings of lowland tropical forest in Singapore. Biotropica 28, 636-648.

Burslem, D.F.R.P., Grubb, P.J., Turner, I.M., 1995. Responses to nutrient addition among shade-tolerant tree seedlings of lowland tropical rain-forest in Singapore. Journal of Ecology 83, 113-122.

Burslem, D.F.R.P., Turner, I.M., Grubb, P.J., 1994. Mineral nutrient status of coastal hill dipterocarp forest and adinandra belukarin Singapore: bioassays of nutrient limitation. Journal of Tropical Ecology 10, 579-599.

Canham, E.D., Finzi, A.E., Pacala, S.W., Burbank, D.H., 1994. Causes and consequences of resource heterogeneity in forests-interspecific variation in light transmission by canopy trees. Canadian Journal of Forest Research 24, 337-349.

Carmean, W.H., 1979. Soil-site factors affecting hardwood regeneration and growth. In: Regenerating Oaks in Upland Hardwood Forests: Proceedings 61.

Chapin, F.S., Autumn, K., Pugnaire, F., 1993. Evolution of suites of traits in response to environmental stress. American Naturalist 142, S78-S92.

Chave, J., Condit, R., Aguilar, S., Hernandez, A., Lao, S., Perez, R., 2004. Error propagation and scaling for tropical forest biomass estimates. Philosophical Transactions of the Royal Society London B 359, 409-420.

Clark, J.S., 2010. Individuals and the variation needed for high species diversity in forest trees. Science 327, 1,129-1,132.

Condit, R., 1998a. Tropical Forest Census Plots: Methods and Results from Barra Colorado Island, Panama and a Comparison with Other Plots. Springer, Berlin.

Coomes, D.A., Allen, R.B., 2007. Effects of size, competition and altitude on tree growth. Ecology Letters 95, 1,084-1,097.

Coomes, D.A., Georges, K., Charles, D.E., Elaine, W., 2009. A greater range of shade-tolerance niches in nutrient-rich forests: an explanation for positive richness-productivity relationships? Journal of Ecology 97, 705-717.

Coomes, D.A, Grubb, P.J., 1998. Responses of juvenile trees to above-and belowground competition in nutrient-starved Amazonian rain forest. Ecology 79, 768-792.

Condit, R., 1998b. Tropical Forest Census Plots: Methods and Results from Barra Colorado Island, Panama and a Comparison with Other Plots. Springer-Verlag, Berlin.

Davies, S.J., Palmiotto, P.A., Ashton, P.S., Lee, H.S., Lafrankie, J.V., 1998 Comparative ecology of 11 sympatric species of Macaranga in Borneo: tree distribution in relation to horizontal and vertical resource heterogeneity. Journal of Ecology 86, 662-673.

Davies, S.J., Tan, S., LaFrankie, J.V., Potts, M.D., 2005. Soil-related floristic variation in the hyperdiverse dipterocarp forest in Lambir Hills, Sarawak. Pollination Ecology and Rain Forest Diversity. In: Roubik, D.W., Sakai, S. Hamid, A. (editors), Sarawak Studies. Springer-Verlag, New York, New York, pp. 22-34

deWilde, W.J.J.O., 2000. Myristicaceae. Flora Malesiana 14, 1-634

Dietze, M.E., Wolosin, M.S., Clark, J.S., 2008. Capturing diversity and interspecific variability in allometries: a hierarchical approach. Forest Ecology and Management 256, 1,939-1,948.

Enquist, B.J., West, G.B., Charnov, E.L., Brown, J.H., 1999. Allometric scaling of production and life-history variation in vascular plants. Nature 401, 907-911.

Fournier, M., Stokes, A., Coutand, E., Fourcaud, T., Moulia, B., 2006. Tree biomechanics and growth strategies in the context of functional ecology. In Herrel, T.S.A, Rowe, N.P. (editors), Ecology and Biomechanics. CRC Press, Taylor \& Francis Group, Boca Raton, FL, pp. 1-33.

Fox, J., 2008. Applied Regression Analysis and Generalized Linear Models, 2nd edition. Sage, Thousand Oaks, California.

Fox, J., Bates, D., Firth, D., Friendly, M., Gorjanc, G., Graves, S., Heiberger, R., Monette, G., Nilsson, H., Ogle, D., Ripley, B., Weisberg, S., Zeileis, A., 2009. Car: Companion to Applied Regression. $R$ package version 1.2-16. http:// CRAN.Rproject.orgipackage $=$ car

Fraser, A.I., 1962. The soil and roots as factors in tree stability. Forestry 35 $117-127$.

Givnish, T., 1988. Adaptation to sun and shade: a whole-plant perspective. Australian Journal of Plant Physiology 15, 63-92.

Givnish, T.J., 1995. Plant stems: biomechanical adaptation for energy capture and influence on species distributions. In: Gartner, B.L. (editor), Plant Stems. Academic Press, New York, New York, pp. 3-49.

Goldberg, D.E., 1996. Competitive ability: definitions, contingency and correlated traits. Philosophical Transactions: Biological Sciences 351, 1,377-1,385.

Greenhill, A.G., 1881. Determination of the greatest height consistent with stability that a vertical pole or mast can be made, and the greatest height to which a tree of given proportions can grow. Proceedings of the Cambridge Philosophical Society, volume 4, pp. 65-73.

Grime, J.P., 1979. Plant Strategies and Vegetation Processes. John Wiley and Sons, New York, New York.

Grubb, P.J., 1977. The maintenance of species-richness in plant communities: the importance of the regeneration niche. Biological Reviews 52, 107-145.

Grubb, P.J., 1989. The role of mineral nutrients in the tropics: a plant ecologist's view. In: Proctor, J. (editor), Mineral Nutrients in Tropical Forest and Savanna Ecosystems. Blackwell Scientific, Oxford.

Grubb, P.J., Lee, W.G., Kollmann, J., Wilson, J.B., 1996. Interaction of irradi- 
ance and soil nutrient supply on growth of seedlings of ten European tallshrub species and Fagus sylvatica. Journal of Ecology 84, 827-840.

Halle, F., Oldeman, R.A.A., Tomlinson, P.B., 1978. Tropical Trees and Forests: An Architectural Analysis. Springer-Verlag, Berlin, 441.

Henry, H.A.L., Thomas, S.C., 2002. Interactive effects of lateral shade and wind on stem allometry, biomass allocation, and mechanical stability in Abutilon theophrasti (Malvaceae). American Journal of Botany 89, 1,609-1,615.

Horn, H.S., 1971. The Adaptive Geometry of Trees. Princeton University Press, Princeton, NJ.

Hurtt, G.C., Pacala, S.W., 1995. The consequences of recruitment limitation: reconciling chance, history, and competitive differences between plants. Journal of Theoretical Biology 176, 1-12.

King, D.A., 1981. Tree dimensions: maximizing the rate of height growth in dense stands. Oecologia 51, 351-356.

King, D.A., 1990a. The adaptive significance of tree height. American Naturalist $135,809-828$.

King, D.A., 1990b. Allometry of saplings and understorey trees of a Panamanian forest. Functional Ecology 4, 27-32.

King, D.A., 1994. Influence of light level on the growth and morphology of saplings in a Panamanian forest. American Journal of Botany 81, 948-957.

Kobe, R.K., 1999. Light gradient partitioning among tropical tree species through differential seedling mortality and growth. Ecology 80, 187-207.

Kobe, R.K., Pacala, S.W., Silander, J.A., Canham, C.D., 1995.Juvenile tree survivorship as a component of shade tolerance. Ecological Applications 5, 517-532.

Kohyama, T., 1987. Significance of architecture and allometry in saplings. Functional Ecology 1, 399-404.

Kohyama, T., 1991. A functional model describing sapling growth under a tropical forest canopy. Functional Ecology 5, 83-90.

Kohyama, T., Hotta, M., 1990. Significance of allometry in tropical saplings. Functional Ecology 4, 515-521.

Kohyama, T., Suzuki, E., Aiba, S., Seino, T., 1999. In: Kato, M. (editor), Functional differentiation and positive feedback enhancing plant biodiversity. The Biology of Biodiversity. Springer-Verlag, Tokyo, pp. 179-191.

Kohyama, T., Suzuki, E., Partomihardjo, T., Yamada, T., Kubo, T., 2003. Tree species differentiation in growth, recruitment and allometry in relation to maximum height in a Bornean mixed dipterocarp forest. Journal of Ecology 91, 797-801.

Kohyama, T., Kubo, T., Macklin, E., 2005. Effect of temporal autocorrelation on apparent growth rate variation in forest tree census data and an alternative distribution function of tree growth rate. Ecological Research 20, 11-15.

Latham, R.E., 1992. Co-occurring tree species change rank in seedling performance with resources varied experimentally. Ecology 73, 2,129-2,144.

Larjavaraara, M., Muller-Landau, H.C., 2010. Rethinking the value of high wood density. Functional Ecology 24, 701-705.

Laurance, W.F., Nascimento, H.E.M., Laurance, S.G., Condit, R., D'Angelo, S., Andrade, A., 2004. Inferred longevity of Amazonian rainforest trees based on a long-term demographic study. Forest Ecology and Management 190, 131-143.

Lee, H.S., Davies, S.J., LaFrankie, J.V., Tan, S., Yamakura, T., Itoh, A., Ohkubo, T., Ashton, O., 2002. Floristic and structural diversity of mixed dipterocarp forests in Lambir Hills National Park, Sarawak, Malaysia. Journal of Tropical Forest Science 14, 379-400.

Lewis, S.L., Tanner, E.V.J., 2000. Effects of above- and belowground competition on growth and survival of rain forest tree seedlings. Ecology $81,2525-2538$.

Monserud, R.A., 1984. Height growth and site index curves for inland douglas-fir based on stem analysis data and forest habitat type. Forest Science 30, 943-965.

Muller-Landau, H.C., Condit, R.S., Chave, J., Thomas, S.C., Bohlman, S.A., Bunyavejchewin, S., Davies, S., Foster, R., Gunatilleke, S., Gunatilleke, N., Harms, K.E., Hart, T., Hubbell, S.P., Itoh, A., Kassim, A.R., LaFrankie, J.V., Lee, H.S., Losos, E., Makana, J.-R., Ohkubo, T., Sukumar, R., Sun, I.E., Nur Supardi, M.N., Tan, S., Thompson, J., Valencia, R., Munoz, G.V., Wills, C., Yamakura, T., Chuyong, G., Dattaraja, H.S., Esufali, S., Hall, P., Hernandez, C., Kenfack, D., Kiratiprayoon, S., 2006. Testing metabolic ecology theory for allometric scaling of tree size, growth and mortality in tropical forests. Ecology Letters 9, 575-588.

NeIder, J.A., Mead, R., 1965. A simplex algorithm for function minimization. Computer Journal 7, 308-313.

Newman, E.I., 1973. Competition and diversity in herbaceous vegetation. $\mathrm{Na}$ ture $244,310-1310$

Niklas, K.J., 1992. Plant Biomechanics: An Engineering Approach to Plant Form and Function. University of Chicago Press, Chicago, Illinois.

Nishimura, T.B., Suzuki, E., 2001. Allometric differentiation among tropical tree seedlings in heath and peat-swamp forests. Journal of Tropical Ecology 17, 667-681.

Pacala, S.W., Rees, M., 1998. Models suggesting field experiments to test two hypotheses explaining successional diversity. American Naturalist 152, $729-737$.

Palmiotto, P.A., Davies, S.J., Vogt, K.A., Ashton, M.S., Vogt, D.J., Ashton, P.S., 2004. Soil-related habitat specialization in dipterocarp rain forest tree species in Borneo. Journal of Ecology 92, 609-623.

Plotkin, J.B., Potts, M.D., Leslie, N., Manokaran, N., LaFrankie, J., Ashton, P.S., 2000. Species-area curves, spatial aggregation, and habitat specialization in tropical forests. Journal of Theoretical Biology 207, 81-99.

Poorter, L., Arets, E., 2003. Light environment and tree strategies in a Boliv- ian tropical moist forest: an evaluation of the light partitioning hypothesis. Plant Ecology 166, 295-306.

Poorter, L., Bongers, F., Sterck, F.J., Wall, H., 2003. Architecture of 53 rain forest tree species differing in adult stature and shade tolerance. Ecology 84 602-608.

Poorter, L., Bongers, L., Bongers, F., 2006. Architecture of 54 moist-forest tree species: traits, trade-offs, and functional groups. Ecology 87, 1,289-1,301.

Potts, M.D., Ashton, P.S., Kaufman, L.S., Plotkin, J.B., 2002. Habitat patterns in tropical rain forests: a comparison of 105 plots in northwest Borneo. Ecology 83, 2,782-2,797.

R Development Core Team, 2009. R: A Language and Environment for Statistical Computing. R Foundation for Statistical Computing. http://www.Rproject.org.

Rose, K.E., Atkinson, R.L., Turnbull, L.A., Rees, M., 2009. The costs and benefits of fast living. Ecology Letters 12, 1,379-1,384.

Russo, S.E., Brown, P., Tan, S., Davies, S.J., 2008. Interspecific demographic trade-offs and soil-related habitat associations of tree species along resource gradients. Journal of Ecology 96, 192-203.

Russo, S.E., Cannon, W.L., Elowsky, C., Tan, S., Davies, S.J., 2010. Variation in leaf stomatal traits of 28 tree species in relation to gas exchange along an edaphic gradient in a Bornean rain forest. American Journal of Botany 97, 1,109-1,120.

Russo, S.E., Davies, S.J., King, D.A., Tan, S., 2005. Soil-related performance variation and distributions of tree species in a Bornean rain forest. Journal of Ecology 93, 879-889.

Russo, S.E., Wiser, S.W., Coomes, D.A, 2007. Growth-size scaling relationships of woody plant species differ from predictions of the Metabolic Ecology Model. Ecology Letters 10, 889-901.

Simpson, W.T., 1993. Specific Gravity, Moisture Content, and Density Relationship for Wood. Forest Products Laboratory General Technical Report.

Sterck, F.J., Bongers, F., Newbery, D.M., 2001. Tree architecture in a Bornean lowland rain forest: intraspecific and interspecific patterns. Plant Ecology $153,279-292$.

Sumida, A., Ito, H., Isagi, Y., 1997. Trade-off between height growth and stem diameter growth for an evergreen Oak Quercus glauca, in a mixed hardwood forest. Functional Ecology 11, 300-309.

Suzuki, E., 1999. Diversity in specific gravity and water content of wood among Bornean tropical rainforest trees. Ecological Research 14, 211-224.

Tan, S., Yamakura, T., Tani, M., Palmiotto, P., Mamit, J.D., Pin, C.S., Davies, S., Ashton, P., Baillie, I., 2009. Review of soils on the 52-ha long term ecological research plot in mixed dipterocarp forest at Lambir, Sarawak Malaysian Borneo. Tropics 18, 61-86.

Thomas, S.C., 1996. Asymptotic height as a predictor of growth and allometric characteristics in Malaysian rain forest trees. American Journal of Botany $83,556-566$.

Tilman, D., 1988. Plant Strategies and the Dynamics and Structure of Plant Communities. Princeton University Press, Princeton, N.J.

Turner, I.M., 1991. Effects of shade and fertilizer addition on the seedlings of two tropical woody pioneer species. Tropical Ecology 32, 24-29.

United Nations Framework Convention on Climate Change, 2008. Conference of the Parties 14, Poznan, December 2008.

United States Department of Agriculture, 1999. Wood Handbook: Wood as an Engineering Material. Forest Products Laboratory General Technical Report FPL-GTR-113.

Valladares, F., Wright, S.J., Lasso, E., Kitajima, K., Pearcy, R.W., 2000. Plastic phenotypic response to light of 16 congeneric shrubs from a Panamanian rainforest. Ecology 81, 1,925-1,936.

Vanclay, J.K., 1992. Assessing site productivity in tropical moist forests: a review. Forest Ecology and Management 54, 257-287.

van Gelder, H.A., Poorter, L., Sterck, F.J., 2006. Wood mechanics, allometry, and lifehistory variation in a tropical rain forest tree community. New Phytologist 171, 367-378.

Wang, J.R., Kimmins, J.P., 2002. Height growth and competitive relationship between paper birch and Douglas-fir in coast and interior of British Columbia. Forest Ecology and Management 165, 285-293.

Warton, D.I., Wright, I.J., Falster, D.S., Westoby, M., 2006. Bivariate line-fitting methods for allometry. Biological Reviews 81, 259-291.

Warton, D., Ormerod, J., 2007. Smatr: (Standardised) major axis estimation and testing routines. $R$ package version 2.1. http://web.maths.unsw.edu. au!. dwarton.

Watson, H., 1985. Lambir Hills National Park: Resource Inventory with Management Recomendations. National Parks and Wildlife Office, Forest Department, Kuching, Sarawak, Malaysia.

Weiner, J., 1990. Asymmetric competition in plant populations. Trends in Ecology and Evolution 5, 360-364

Weiskittel, A.R., Garber, S.M., Johnson, G.P., Maguire, D.A., Monserud, R.A., 2007. Annualized diameter and height growth equations for Pacific Northwest plantation-grown Douglas-fir, western hemlock, and red alder. Forest Ecology and Management 250, 266-278.

Yamada, T., Zuidema, P.A., Itoh, A., Yamakura, T., Ohkubo, T., Kanzako, M., Tan, S., Ashton, P.S., 2007. Strong habitat preference of a tropical rain forest tree does not imply large differences in population dynamics across habitats. Journal of Ecology 95, 332-342.

Yoda, K., 1974. Three-dimensional distribution of light incidence in a tropical rain forest of West Malaysia. Japanese Journal of Ecology 24, 247-254. 
The effect of belowground resources on light-affected allometry in six Bornean tree species: Supplementary materials.

Katherine D. Heineman ${ }^{1 *}$, Ethan Jensen ${ }^{1}$, Autumn Shapland ${ }^{1}$, Brett Bogenrief ${ }^{1}$, Sylvester $\operatorname{Tan}^{3}$, Richard Rebarber ${ }^{2}$, and Sabrina E. Russo ${ }^{1}$.

1 School of Biological Sciences, University of Nebraska-Lincoln, Nebraska, 68508, USA

2 Department of Mathematics, University of Nebraska-Lincoln, Nebraska, 68508, USA

3 Center for Tropical Forest Science and Forest Research Centre, Sarawak Forestry

Corporation, Kuching, Sarawak, Malaysia

*Author for correspondence: kheineman@life.illinois.edu 
Fig SM1. Spatial distributions of six tree species on a 52-ha forest dynamics plot at Lambir Hills

National Park, Sarawak, Borneo. Colors represent soil-types defined in Davies et al. 2005 listed here in order of increasing soil fertility: grey = sandy loam, light green $=$ loam, green $=$ fine loam, and dark green = clay .
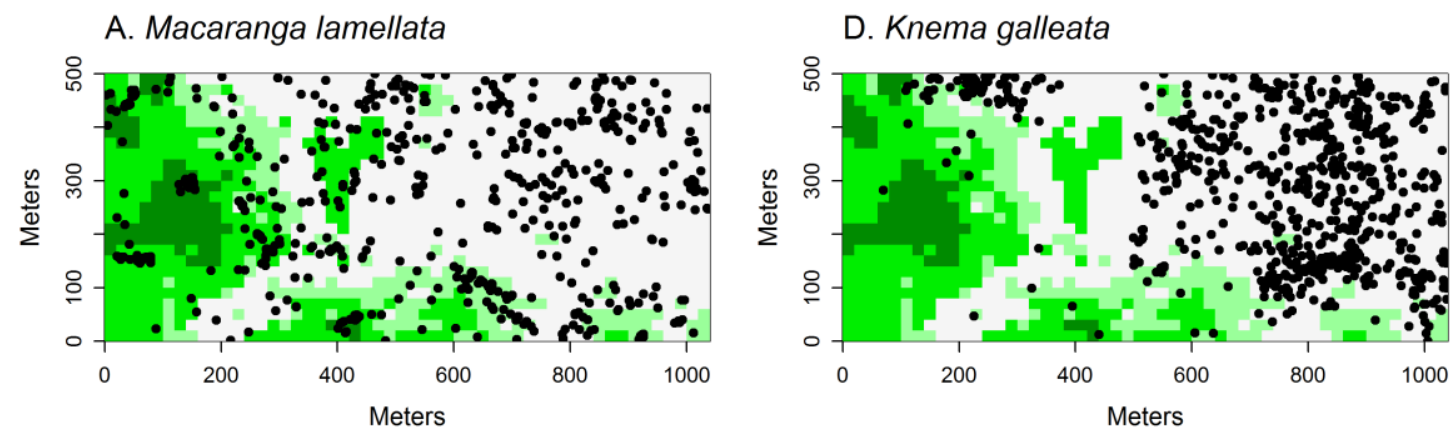

B. Macaranga umbrosa

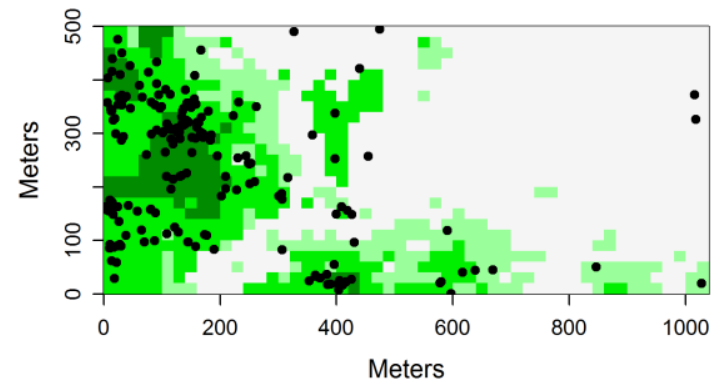

E. Knema elmeri

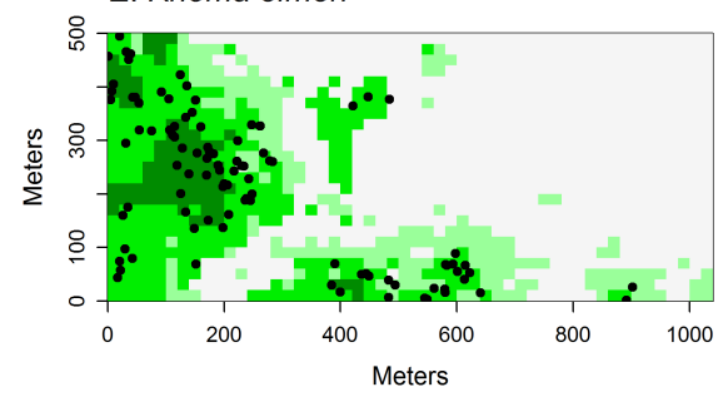

C. Macaranga beccariana
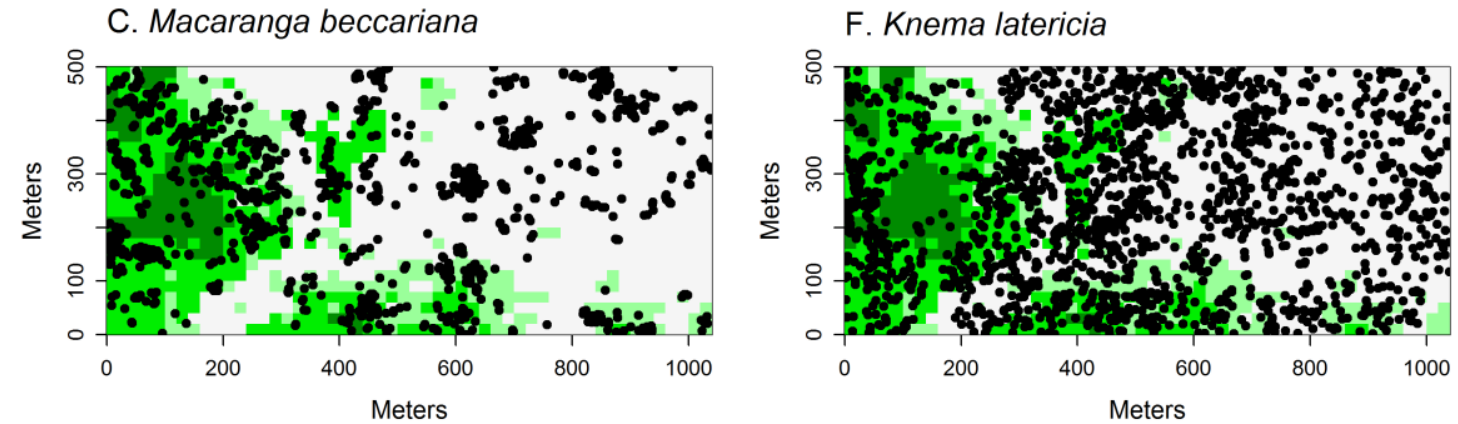
Table SM2. For models of height-diameter (DBH), crown area-DBH, and crown depth-height allometry in six Bornean tree species, AIC values were compared between log-transformed data fitted in ordinary least squares regression (OLS) and for non-log transformed data fitted in nonlinear least squares regression (NLS). See methods section in main text for details.

\begin{tabular}{|c|c|c|c|c|c|c|}
\hline \multirow[b]{2}{*}{ Species } & \multicolumn{2}{|c|}{ Height-DBH AIC } & \multicolumn{2}{|c|}{ Crown Area-DBH AIC } & \multicolumn{2}{|c|}{ Crown Depth-Height AIC } \\
\hline & OLS & NLS & OLS & NLS & OLS & NLS \\
\hline K. galeata & 129.8 & 150.7 & 144.3 & 190.2 & 109.4 & 116.2 \\
\hline K. elmeri & 109.0 & 119.2 & 172.7 & 225 & 97.5 & 113.3 \\
\hline M. lamellata & 140.5 & 165.8 & 168.5 & 195 & 100.9 & 129 \\
\hline M. umbrosa & 170.2 & 169.6 & 179 & 284.4 & 113.8 & 147.8 \\
\hline K. latericia & 260.4 & 270 & 273.5 & 384.8 & 215.1 & 215 \\
\hline sandy loam & 146.7 & 137.3 & 139.1 & 191.3 & 115.6 & 97.3 \\
\hline clay-fine loam & 111.9 & 131.4 & 135.5 & 196.2 & 105.2 & 118.8 \\
\hline M. beccariana & 363.0 & 386.2 & 442.6 & 542.7 & 274.1 & 281.5 \\
\hline sandy loam & 185.6 & 190.5 & 233.5 & 261.5 & 158.1 & 149.3 \\
\hline clay-fine loam & 199.5 & 197.5 & 214.1 & 282.7 & 118.2 & 133.7 \\
\hline
\end{tabular}


Table SM3. For allometric relationships modeled in the form $\ln (X)=b^{*} \ln (Y)+\ln (a)$, we present parameters (intercept $=\ln (a)$; slope $=$ b) with $95 \%$ confidence intervals fitted in major-axis regression for six Bornean tree species. For soil generalists, $K$. latericia and $M$. beccariana, we list overall species parameters followed by parameters fitted for conspecific populations sampled on sandy loam and clay-fine loam, respectively.

\begin{tabular}{|c|c|c|c|c|c|c|c|c|c|c|c|c|}
\hline \multirow[b]{3}{*}{ Species } & \multicolumn{6}{|c|}{ Height-DBH } & \multicolumn{6}{|c|}{ Crown Area-DBH } \\
\hline & \multicolumn{3}{|c|}{ intercept } & \multicolumn{3}{|c|}{ slope } & \multicolumn{3}{|c|}{ intercept } & \multicolumn{3}{|c|}{ slope } \\
\hline & mean & lower & upper & mean & lower & upper & mean & lower & upper & mean & lower & upper \\
\hline K. galeata & 0.87 & 0.71 & 1.03 & 0.83 & 0.74 & 0.92 & -0.6 & -1.13 & -0.06 & 1.24 & 0.97 & 1.61 \\
\hline K. elmeri & 0.62 & 0.46 & 0.79 & 0.76 & 0.68 & 0.84 & -0.67 & -1.15 & -0.2 & 1.55 & 1.34 & 1.81 \\
\hline M. lamellata & 0.85 & 0.69 & 1.02 & 0.89 & 0.78 & 1.03 & -1.05 & -1.62 & -0.48 & 1.94 & 1.56 & 2.49 \\
\hline M. umbrosa & 0.72 & 0.52 & 0.92 & 0.9 & 0.75 & 1.07 & -2.27 & -3.07 & -1.47 & 2.55 & 2.03 & 3.36 \\
\hline K. latericia & 0.49 & 0.45 & 0.73 & 0.89 & 0.79 & 1.00 & -1.30 & -1.64 & -0.96 & 1.83 & 1.61 & 2.10 \\
\hline sandy loam & 0.7 & 0.49 & 0.9 & 0.86 & 0.73 & 1.00 & -1.43 & -1.88 & -0.99 & 1.81 & 1.55 & 2.14 \\
\hline clay-fine loam & 0.51 & 0.32 & 0.71 & 0.89 & 0.75 & 1.06 & -1.2 & -1.75 & -0.65 & 1.89 & 1.52 & 2.42 \\
\hline M. beccariana & 1.17 & 1.00 & 1.34 & 0.66 & 0.58 & 0.75 & -1.95 & -2.47 & -1.44 & 2.05 & 1.81 & 2.34 \\
\hline sandy loam & 1.3 & 1.02 & 1.57 & 0.61 & 0.49 & 0.75 & -1.91 & -2.81 & -1.01 & 2.01 & 1.64 & 2.53 \\
\hline clay-fine loam & 1.14 & 0.92 & 1.37 & 0.66 & 0.54 & 0.79 & -2.02 & -2.72 & -1.32 & 2.12 & 1.79 & 2.57 \\
\hline
\end{tabular}


Table SM3. (Continued).

\begin{tabular}{|c|c|c|c|c|c|c|}
\hline \multirow[b]{3}{*}{ Species } & \multicolumn{6}{|c|}{ Crown Depth-Height } \\
\hline & \multicolumn{3}{|c|}{$\underline{\text { intercept }}$} & \multicolumn{3}{|c|}{ slope } \\
\hline & mean & lower & upper & mean & lower & upper \\
\hline K. galleata & -5.35 & -8.04 & -2.65 & 2.53 & 1.76 & 4.73 \\
\hline K. elmeri & -1 & -1.52 & -0.5 & 1.05 & 0.83 & 1.33 \\
\hline M. lamellata & -3.91 & -6.83 & -0.98 & 2.15 & 1.14 & 6.73 \\
\hline M. umbrosa & -5.04 & -7.05 & -3.02 & 2.82 & 1.99 & 4.55 \\
\hline K. latericia & -1.56 & -2.06 & -1.08 & 1.28 & 1.04 & 1.60 \\
\hline sandy loam & -1.66 & -2.28 & -1.04 & 1.25 & 0.97 & 1.63 \\
\hline clay-fine loam & -1.88 & -2.82 & -0.94 & 1.58 & 1.11 & 2.4 \\
\hline M. beccariana & -5.53 & -7.05 & -4.02 & 2.60 & 2.08 & 3.38 \\
\hline sandy loam & -8.29 & -11.8 & -4.76 & 3.59 & 2.57 & 5.75 \\
\hline clay-fine loam & -4.44 & -6.25 & -2.64 & 2.19 & 1.58 & 3.32 \\
\hline
\end{tabular}


Table SM4. Parameters for allometric power function models of diameter growth rate, height, and crown area allometry fit using nonlinear least squares regression used to predict height and crown area growth in six Bornean tree species. The longevity of each tree species was estimate to provide reasonable axes for growth projections.

\section{Growth Rate-DBH Height-DBH Crown Area-DBH Estimated Longevity (years)}

\begin{tabular}{|c|c|c|c|c|c|c|c|}
\hline Species & $\alpha$ & $\beta$ & $\mathrm{a}$ & $\mathrm{b}$ & $\mathrm{a}$ & $\mathrm{b}$ & \\
\hline K. galeata & 0.04 & 0.06 & 3.05 & 0.71 & 1.42 & 0.80 & 300 \\
\hline K. elmeri & 0.33 & 0.07 & 1.76 & 0.78 & 2.18 & 0.96 & 165 \\
\hline M. lamellata & 0.15 & -0.20 & 2.79 & 0.78 & 0.94 & 1.26 & 105 \\
\hline M. umbrosa & 0.09 & 0.32 & 2.53 & 0.76 & 0.83 & 1.24 & 128 \\
\hline K. latericia & & & & & & & 360 \\
\hline sandy loam & 0.02 & 0.28 & 2.20 & 0.81 & 0.36 & 1.55 & - \\
\hline clay-fine loam & 0.04 & 0.06 & 1.83 & 0.83 & 0.57 & 1.44 & - \\
\hline M. beccariana & & & & & & & 28 \\
\hline sandy loam & 0.38 & -0.09 & 5.0 & 0.48 & 0.55 & 1.43 & - \\
\hline clay & 1.26 & -0.26 & 3.3 & 0.64 & 0.25 & 1.83 & - \\
\hline
\end{tabular}


Table SM5. Parameters of allometric relationships $\left(\ln (X)=b^{*} \ln (Y)+\ln (a)\right)$ fit using ordinary least squares regression with $95 \%$ upper and lower confidence limits for six Bornean tree species (intercept $=\ln (a)$; slope $=b$ ). For generalists we list overall species parameters followed by parameters fitted for conspecific populations on sandy loam and clay-fine loam.

\begin{tabular}{|c|c|c|c|c|c|c|c|c|c|c|c|c|}
\hline \multirow[b]{3}{*}{ Species } & \multicolumn{6}{|c|}{ Height-DBH } & \multicolumn{6}{|c|}{ Crown Area-DBH } \\
\hline & \multicolumn{3}{|c|}{ intercept } & \multicolumn{3}{|c|}{ slope } & \multicolumn{3}{|c|}{ intercept } & \multicolumn{3}{|c|}{ slope } \\
\hline & mean & lower & upper & mean & lower & upper & mean & lower & upper & mean & lower & upper \\
\hline K. galeata & 0.95 & 0.80 & 1.10 & 0.79 & 0.70 & 0.87 & -0.16 & -0.62 & 0.29 & 0.98 & 0.72 & 1.23 \\
\hline K. elmeri & 0.66 & 0.49 & 0.83 & 0.74 & 0.66 & 0.82 & -0.40 & -0.84 & 0.05 & 1.40 & 1.17 & 1.62 \\
\hline M. lamellata & 0.92 & 0.77 & 1.07 & 0.83 & 0.72 & 0.95 & -0.49 & -0.94 & -0.05 & 1.46 & 1.13 & 1.80 \\
\hline M. umbrosa & 0.85 & 0.67 & 1.03 & 0.79 & 0.66 & 0.93 & -1.22 & -1.77 & -0.66 & 1.68 & 1.26 & 2.10 \\
\hline K. latericia & 0.68 & 0.55 & 0.82 & 0.81 & 0.72 & 0.91 & -0.87 & -1.16 & -0.58 & 1.49 & 1.29 & 1.69 \\
\hline sandy loam & 0.78 & 0.59 & 0.98 & 0.79 & 0.67 & 0.92 & -1.09 & -1.49 & -0.70 & 1.56 & 1.31 & 1.81 \\
\hline clay-fine loam & 0.62 & 0.44 & 0.80 & 0.81 & 0.67 & 0.95 & -0.68 & -1.13 & -0.24 & 1.44 & 1.11 & 1.78 \\
\hline M. beccariana & 1.28 & 1.12 & 1.44 & 0.60 & 0.52 & 0.68 & -1.19 & -1.60 & -0.77 & 1.65 & 1.44 & 1.86 \\
\hline sandy loam & 1.41 & 1.15 & 1.67 & 0.55 & 0.43 & 0.68 & -1.02 & -1.72 & -0.33 & 1.57 & 1.23 & 1.89 \\
\hline clay-fine loam & 1.24 & 1.03 & 1.45 & 0.60 & 0.49 & 0.72 & -1.29 & -1.86 & -0.72 & 1.71 & 1.40 & 2.01 \\
\hline
\end{tabular}


Table SM5 (Continued).

\begin{tabular}{|c|c|c|c|c|c|c|c|c|c|c|c|c|}
\hline \multirow[b]{3}{*}{ Species } & \multicolumn{6}{|c|}{ Crown Depth-Height } & \multicolumn{6}{|c|}{ Safety Factor-DBH } \\
\hline & \multicolumn{3}{|c|}{ intercept } & \multicolumn{3}{|c|}{$\underline{\text { slope }}$} & \multicolumn{3}{|c|}{$\underline{\text { intercept }}$} & \multicolumn{3}{|c|}{$\underline{\text { slope }}$} \\
\hline & mean & lower & upper & mean & lower & upper & mean & lower & upper & mean & lower & upper \\
\hline K. galleata & -1.46 & -2.41 & -0.51 & 0.93 & 0.52 & 1.33 & 0.42 & 0.27 & 0.58 & -0.12 & -0.20 & -0.04 \\
\hline K. elmeri & -0.7 & -1.15 & -0.24 & 0.89 & 0.68 & 1.10 & 0.71 & 0.54 & 0.87 & -0.07 & -0.16 & 0.01 \\
\hline M. lamellata & -1.01 & -1.89 & -0.13 & 0.62 & 0.18 & 1.07 & 0.47 & 0.31 & 0.62 & -0.17 & -0.29 & -0.06 \\
\hline M. umbrosa & -1.99 & -2.73 & -1.25 & 1.17 & 0.78 & 1.57 & 0.52 & 0.34 & 0.71 & -0.13 & -0.26 & 0.01 \\
\hline K. latericia & -0.91 & -1.26 & -0.56 & 0.9 & 0.71 & 1.09 & 0.68 & 0.55 & 0.82 & -0.15 & -0.24 & -0.06 \\
\hline sandy loam & -1.12 & -1.61 & -0.64 & 0.97 & 0.72 & 1.21 & 0.58 & 0.39 & 0.78 & -0.13 & -0.25 & -0.01 \\
\hline clay-fine loam & -0.81 & -1.37 & -0.25 & 0.89 & 0.54 & 1.22 & 0.75 & 0.57 & 0.93 & -0.14 & -0.28 & 0.00 \\
\hline M. beccariana & -2.6 & -3.42 & -1.78 & 1.39 & 1.06 & 1.72 & 0.12 & -0.03 & 0.28 & 0.07 & -0.01 & 0.14 \\
\hline sandy loam & -3.5 & -5.1 & -1.91 & 1.74 & 1.12 & 2.36 & -0.01 & -0.27 & 0.25 & 0.11 & -0.01 & 0.23 \\
\hline clay-fine loam & -2.11 & -3.08 & -1.13 & 1.18 & 0.76 & 1.59 & 0.16 & -0.05 & 0.37 & 0.06 & -0.05 & 0.17 \\
\hline
\end{tabular}

